\title{
Umjetnost na margini?
}

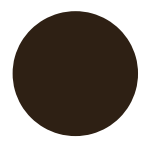

Razgovor sa dr.sc. Sanjom Kojić Mladenov, autoricom izložbe My Art is My Reality, Mali salon Muzeja moderne i suvremene umjetnosti u Rijeci, 9. studenoga -7. prosinca 2018.

DOI: 10.31664/zu.2018.103.09

Sanja Kojić Mladenov viša je kustosica u Muzeju savremene umetnosti Vojvodine u Novom Sadu; povjesničarka je umjetnosti koja je u svome radu usmjerena na istraživanje odnosa suvremene umjetničke prakse, medija i roda. Fokus pri tome stavlja na diskriminatorne politike s naglaskom na isključivanju drugih/drugačijih, što je vidljivo u okviru njezina stručnog i znanstvenog djelovanja na interdisciplinarnim studijima Univerziteta u Novom Sadu-ACIMSI (Asocijacija centara za interdisciplinarne i multidisciplinarne studije i istraživanja). Na ovaj smjer nadovezuje se i njezin angažman kao kustosice na međunarodnoj grupnoj izložbi My Art is My Reality (Moja umjetnost je moja stvarnost) održanoj od 9. studenoga do 7. prosinca 2018. godine u Malom salonu, galerijskom prostoru Muzeja moderne i suvremene umjetnosti u Rijeci. Pokrenuta povodom stogodišnjice završetka Prvoga svjetskog rata, izložba se bavi upravo marginalnim identitetima i marginalnim umjetničkim praksama u odnosu na promjenjive pozicije moći i vladajuće stavove te ističe nužnost pomirenja kroz propitivanje nasilnih odnosa i nepravdi. lako se projekt bavi revalorizacijom povijesnih narativa, tema itekako rezonira u današnjici s obzirom na sve veći zamah desnih radikalizama i ekstremizama te homofobnih i diskriminatornih stavova. O mogućnostima kroz koje umjetnost zaista može upozoravati i/ili djelovati u kontekstu društveno-političkih nepravdi, a na primjeru izložbe My Art is My Reality i pozvanih umjetnika i umjetnica, razgovarali smo sa Sanjom Kojić Mladenov. 


\section{Kunst am Rande?}

O

Gespräch mit Dr. Sanja Kojić Mladenov, Autorin der Ausstellung My Art is My Reality, Kleiner Salon des Museums für moderne und zeitgenössische Kunst in Rijeka, 9. November-7. Dezember 2018 DOI: 10.31664/zu.2018.103.09

Sanja Kojić Mladenov ist Höhere Kuratorin im Museum für zeitgenössische Kunst Vojvodina in Novi Sad und Kunsthistorikerin, die bei ihrer Arbeit die künstlerische Praxis, die Medien und die Geschlechter erforscht. Dabei liegt ihr Fokus auf der Diskriminierungspolitik mit Schwerpunkt auf dem Ausschluss der Anderen/ Andersartigen, was auch bei ihrer wissenschaftlichen und fachlichen Tätigkeit im Rahmen der interdisziplinären Studien der Universität Novi Sad-ACIMSI (Verband der Zentren für inter- und multidisziplinäre Studien und FoschungAsocijacija centara za interdisciplinarne i multidisciplinarne studije i istraživanja) sichtbar ist. Darauf baut auch ihr Engagement als Kuratorin der internationalen Gruppenausstellung My Art is My Reality (Meine Kunst ist meine Realität) auf, die vom 9. November bis zum 7. Dezember 2018 im Kleinen Salon, dem Galeriebereich des Museums für moderne und zeitgenössische Kunst in Rijeka stattfand. Angeregt durch den hundertsten Jahrestag vom Ende des Ersten Weltkriegs befasst sich die Ausstellung mit Randidentitäten und künstlerischen Randpraktiken im Verhältnis zu den veränderlichen Positionen der Macht und der vorherrschenden Einstellung und betont das Erfordernis der Aussöhnung durch Hinterfragung gewalttätiger Beziehungen und Ungerechtigkeiten. Obwohl sich das Projekt mit der Neubewertung der historischen Geschichtsschreibung befasst, spiegelt sich das Thema wegen des immer stärker ausgeprägten Rechtsradikalismus und Extremismus sowie homophober und diskriminatorischer Einstellungen auch in der heutigen Zeit wider. Über die Möglichkeiten, wie Kunst am Beispiel der Ausstellung My Art is My Reality und der eingeladenen Künstler und Künstlerinnen im Kontext der sozialen und politischen Ungerechtigkeiten warnen und/oder wirken kann, haben wir mit Sanja Kojić Mladenov gesprochen.

$\rightarrow$ 


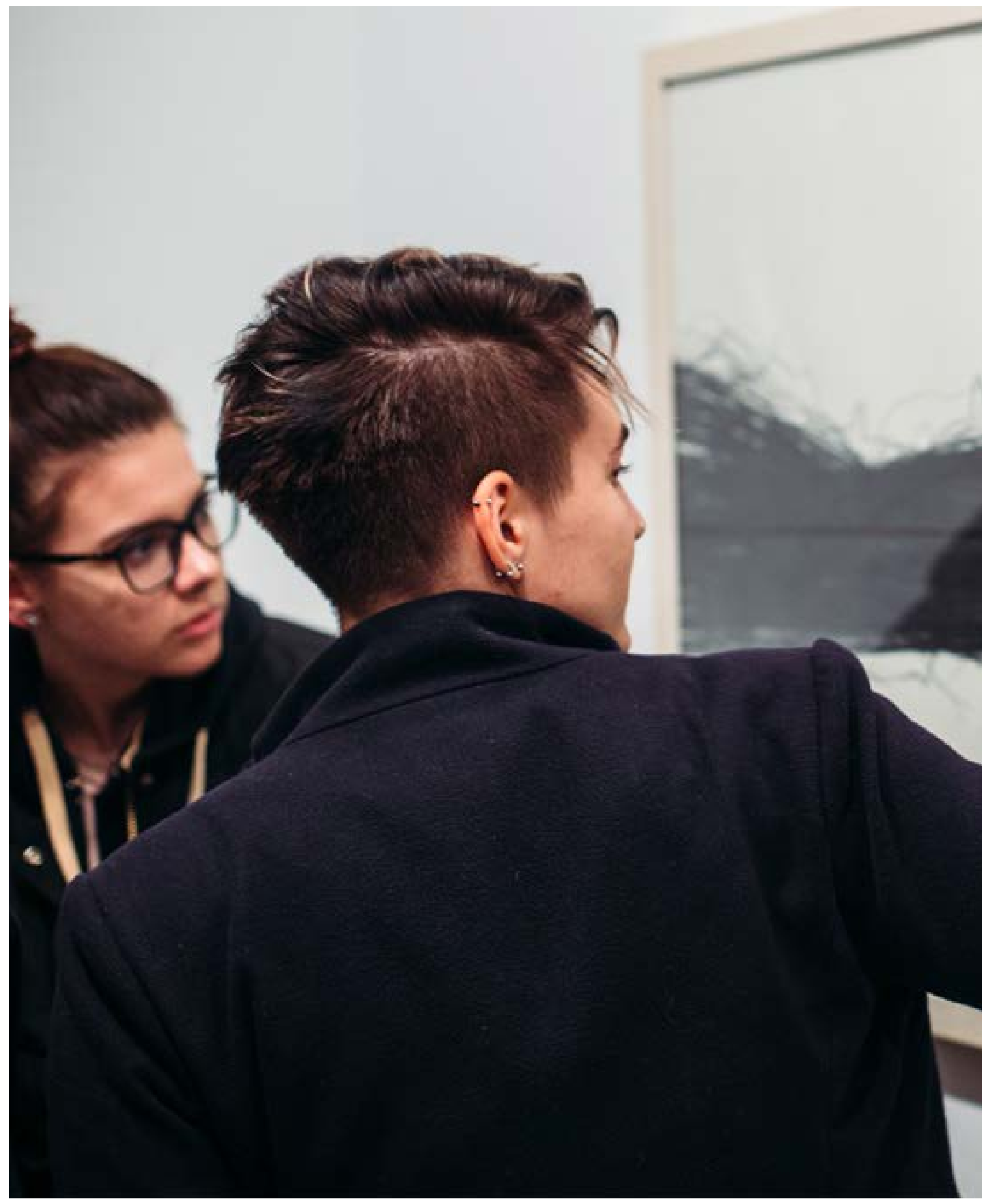




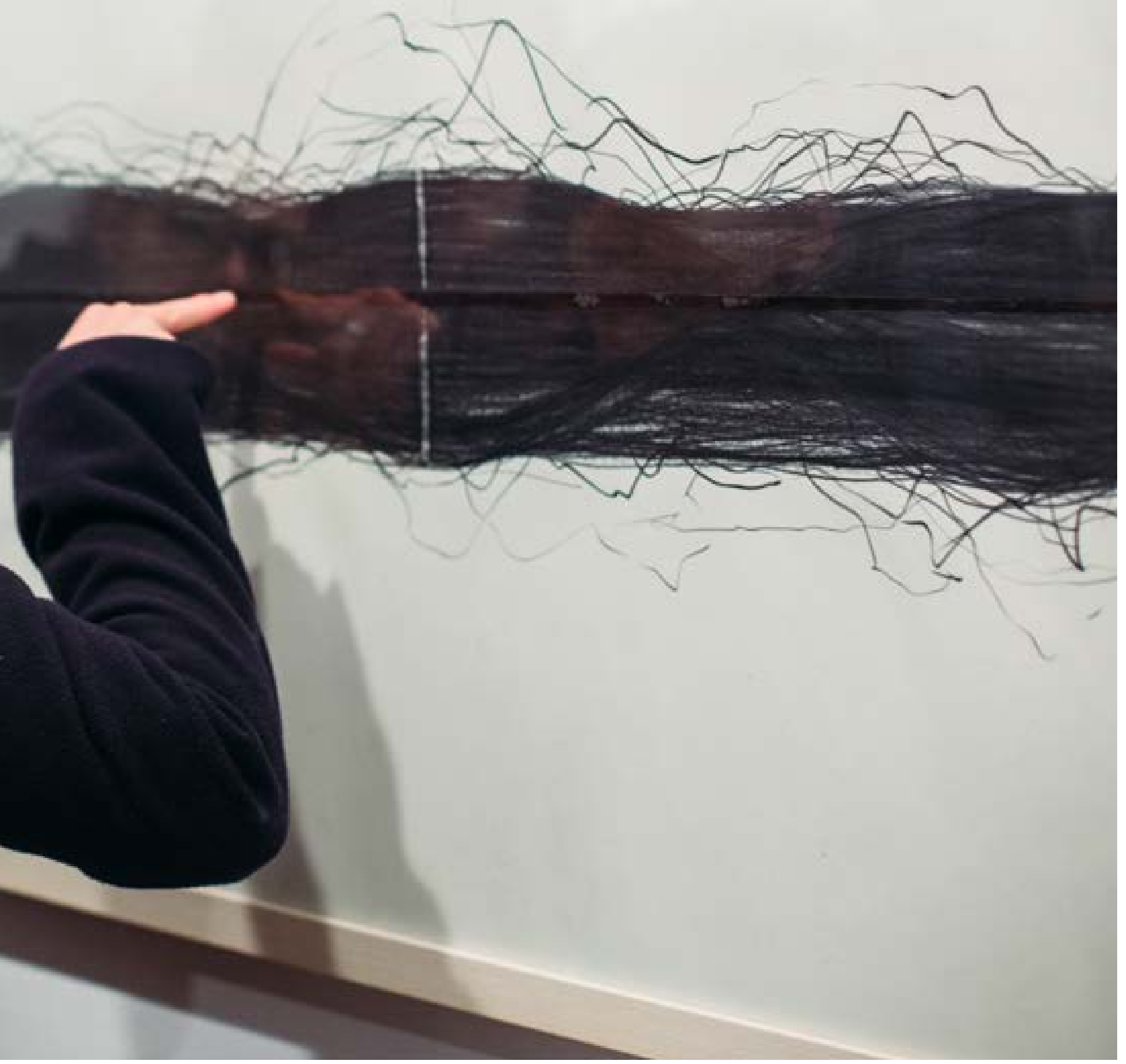

S postava izložbe Moja umjetnost je moja stvarnost, Mali Salon, Muzej moderne i suvremene umjetnosti, Rijeka, 2018. Foto: Stephany Stefan / Von der Ausstellung Meine Kunst ist meine Realität, Kleiner Salon des Museums für moderne und zeitgenössische Kunst, Rijeka, 20I8. Foto: Stephany Stefan $\uparrow$ 
Marina Tkalčić (мт)

Sanja Kojić Mladenov (sкM)

MT Pozvana ste kustosica izložbe My Art is My Reality unutar istoimenog projekta; kako je došlo do ove suradnje? Jeste li se i u prethodnim projektima i izložbama bavili sličnim pitanjima - pitanjima manjinskih i marginaliziranih grupa, društvenim i kulturnim isključivanjima, (post)ratnim prilikama i traumama i sličnim?

skM Goethe-Institut i Institut français u Hrvatskoj pokrenuli su projekat usmeren k ispitivanju i revalorizaciji pitanja memorije na nasilnu prošlost i pomirenje kroz izgradnju zajedničke budućnosti u Evropi. Neposredni povod za ispitivanje ovih ključnih problema je obeležavanje stogodišnjice završetka Prvog svetskog rata 2018. godine, sećanja na turbulentne i nasilne društveno-političke prilike, na traume, migracije i suživot, a kroz savremeni i umetnički kontekst-međunarodni projekat My Art is My Reality čiji segment čini istoimena izložba realizovana u saradnji sa Muzejem moderne i suvremene umjetnosti u Rijeci.

Tema memorije i pomirenja od velike je važnosti za stalno preispitivanje i izgradnju evropske perspektive i pozicije u savremenom multipolarnom svetu, naročito kroz uključivanje manjinskih grupa i njihovih viđenja unutar globalne kulture sećanja i norme uvažavanja različitosti. Istovremeno, to je tema kojom sam se bavila u nekim prethodim projektima. Izložba Memorija nasilja i snovi o budućnosti (2014), 'realizovana u saradnji sa Goethe-Institutom u Beogradu i L'Institut français de Serbie u Muzeju savremene umetnosti Vojvodine, koja je nakon Novog Sada predstavljena u Cetinju i u Mariboru, bila je neposredni povod za novu saradnju, kao i osnova za kreiranje novog koncepta o povezanosti umetnosti i društvene stvarnosti. $U$ fokusu je te perspektive propitivanje zaboravljenih istorija i pozicije marginalnih grupa, naročito romske manjine na Balkanu. Usmerenost na razmatranje mesta pojedinca/pojedinke unutar turbulentnih društvenih procesa i odnosa te diskriminatorne politike isključivanja drugosti podstaknuta je rodnim politikama moći na koje sam usmerena u okviru svoje akademske sfere, na ACIMSI-Centru za rodne studije u Novom Sadu.

мт Kako je tekao proces odabira umjetnika koje ste pozvali da sudjeluju na izložbi? Kojim ste se kriterijima i vrijednostima vodili pri selekciji radova?

sкM Izložba My Art is My Reality bavi se ispitivanjem promenljivih pozicija moći, različitih geopolitičkih interesa, menjanja strana i uloga, a kroz analiziranje pitanja dokumentovanja istorije, postojanja prikrivenih i zaboravljenih arhiva te građenja identiteta na osnovu vladajućih stavova i odnosa. Dugo očekivano pomirenje po završetku Prvog svetskog rata otvorilo je nova pitanja i probleme, a nova teritorijalna i ekonomska podela nove izazove i patnje koji su doprineli izbijanju Drugog svetskog rata. Teret prošlosti utjecao je na izgradnju budućnosti te doveo do novih sukoba i podela tokom 1990-ih godina na području Balkana. Istovremeno, na margini društvenih procesa, trajala je istorija stradanja i diskriminacije Roma, koja je postala ključna odlika njihovog nacionalnog identiteta.

Međunarodna izložba je zato koncipirana kroz učešće umetnika, umetnica i umetničkih grupa koji se bave (re)interpretacijom memorije nasilja i njezinih diskurzivnih taloga, (de)konstrukcijom pamćenja i projekcijom novih (mikro) istorija kroz pomirenje i zajedništvo, kao i pozicioniranjem osobnih fluidnih identiteta unutar globalnih procesa. Izabrani umetnici i umetnice primenjuju studije slučaja iz prošlosti, arhivsku građu ili lična iskustva kao resurs za njihovu rekontekstualizaciju i novo predstavljanje. Cilj izložbe je ukazivanje na značaj sećanja na nasilna i traumatična iskustva, ali i na važnost pomirenja i očuvanja zajedništva kroz savremenu umetničku praksu te ispitivanje pozicije kolektivnog i osobnog identiteta kao promenljive kategorije direktno povezane s društvenim procesima.

\section{1}

Produkcija izložbe: Goethe-Institut Beograd, L'Institut français de Serbie, Muzej savremene umetnosti Vojvodine; kustoskinja: Sanja Kojić Mladenov; podrška: Francusko-nemački fond (Elysée Fund). Izložba je realizirana prvo u Muzeju savremene umetnosti Vojvodine, Novi Sad, Srbija (2014), a zatim u Narodnom muzeju Crne Gore-Galerija savremene umjetnosti Dado Đurić, Cetinje, Crna Gora i Multimedijalnom centru Kibla, Maribor, Slovenija (2015). 
Marina Tkalčić (мт)

Sanja Kojić Mladenov (sкм)

мт Sie wurden eingeladen, als Kuratorin der Ausstellung My Art is My Reality im Rahmen des gleichnamigen Projektes mitzuwirken; wie kam es zu dieser Zusammenarbeit? Haben Sie sich bei Ihren vorhergehenden Projekten und Ausstellungen mit ähnlichen Fragen - Minderheiten, Randgruppen, gesellschaftlichen und kulturellen Ausschlüssen, (Nach)Kriegssituationen und Traumata u.ä.-befasst?

Das Goethe-Institut in Kroatien und das Institut français in Kroatien haben ein Projekt ins Leben gerufen, das darauf abzielt, die Frage der Erinnerung an die gewalttätige Vergangenheit und der Versöhnung durch den Aufbau einer gemeinsamen Zukunft in Europa zu untersuchen und erneut zu bewerten. Der unmittelbare Anlass für die Untersuchung dieser wichtigen Probleme ist die Begehung des IOO. Jahrestags vom Ende des Ersten Weltkrieges im Jahr 20I8, die Erinnerung an turbulente und gewalttätige gesellschaftspolitische Umstände, an die Traumata, Migrationen und die Koexistenz durch einen zeitgenössischen und künstlerischen Kontext, d.h. durch das internationale Projekt My Art is My Reality, dessen Bestandteil die gleichnamige, in Zusammenarbeit mit dem Museum für moderne und zeitgenössische Kunst in Rijeka realisierte Ausstellung ist.

Das Thema der Erinnerung und Versöhnung ist für die ständige Hinterfragung und die Entstehung einer europäischen Perspektive und Position in der zeitgenössischen multipolaren Welt von besonderer Bedeutung, vor allem durch die Einbeziehung von Minderheitengruppen und ihrer Sichtweise innerhalb der globalen Erinnerungskultur und durch Beachtung ihres Andersseins. Gleichzeitig war das auch das Thema, mit dem ich mich in einigen vorhergehenden Projekten befasst habe. Die Ausstellung Erinnerung an Gewalt und Träume der Zukunft (20I4), ${ }^{1}$ die in Zusammenarbeit mit dem Goethe-Institut in Belgrad und dem L'Institut français de Serbie im Museum für zeitgenössische Kunst Vojvodina realisiert wurde und nach Novi Sad auch in Cetinje und Maribor vorgestellt wurde, war der unmittelbare Anlass für eine neue Zusammenarbeit und diente als Grundlage für die Gestaltung eines neuen Konzeptes der Integration von Kunst und sozialer Realität. Im Fokus dieser Perspektive war die Hinterfragung der vergessenen Geschichte und Position von Randgruppen, insbesondere der Roma-Minderheit auf dem Balkan. Die Ausrichtung auf die Betrachtung der Position eines/einer Einzelnen innerhalb der turbulenten gesellschaftlichen Prozesse und Beziehungen sowie der Diskriminierungspolitik zur Ausgrenzung von Andersartigen wurde durch die geschlechtsbezogenen Politiken der Macht angeregt, mit denen ich mich im Rahmen meiner akademischen Arbeite am ACIMSI-Zenter für Gender-Studien in Novi Sad befasse.

мт Wie verlief das Verfahren zur Auswahl der Künstler, die Sie zur Zusammenarbeit bei der Ausstellung eingeladen haben? Welche Kriterien und Werte waren bei der Auswahl der Werke maßgebend?

sкm Die Ausstellung My Art is My Reality untersucht die variablen Positionen der Macht, unterschiedliche geopolitische Interessen, den Wechsel der Seiten und Rollen durch Analyse der Geschichtsschreibung, die Existenz von versteckten und vergessenen Archiven und die Identitätsschaffung auf Grundlage der vorherrschenden Einstellungen und Verhältnisse. Die lang erwartete Versöhnung nach dem Ende des I. Weltkrieges führte zu neuen Fragen und Problemen und die neue territoriale und wirtschaftliche Teilung zu neuen Herausforderungen und Leiden, die zum Ausbruch des Zweiten Weltkrieges beitrugen. Die Last der Vergangenheit beeinflusste die Gestaltung der Zukunft und führte in den 9oer Jahren auf dem Balkan zu neuen Konflikten und Spaltungen. Zur gleichen Zeit

Produktion der Ausstellung: Goethe-Institut Belgrad, L'Institut français de Serbie, Museum für zeitgenössische Kunst Vojvodina, Kuratorin: Sanja Kojić Mladenov, Unterstützung: Französisch-deutscher Fonds (Elysée Fund). Die Ausstellung wurde zuerst im Museum für zeitgenössische Kunst Vojvodina, Novi Sad, Serbien (20I4) realisiert und dann im Nationalmuseum von Montenegro-Galerie fuir zeitgenössische Kunst Dado Đurić, Cetinje, Montengero und im Multimedialen Zentrum Kibla, Maribor, Slowenien (20I5). 
U izložbu su uključene institucije kulture i pojedinci/ke (umetnici/ce i kustosi/ kinje) iz Nemačke, Francuske, Hrvatske, Srbije, Slovenije, Bosne i Hercegovine, Makedonije, Slovačke, Mađarske, Kanade itd. Među autorima i autorkama su: Kolektiv ISTE koji je inicirala i vodi Andreja Kulunčić, Robert Jankuloski, Herlinde Koelbl, Stevan Kojić, Siniša Labrović, Leray Valérie, Monika Moteska, Branislav Nikolić, Vessna Perunovich, André Jenö Raatzsch, Emília Rigová, Selma Selman i Selman Trtovac. Tokom dosadašnjeg kustoskog i naučnog rada sam sa nekima od njih već imala saradnju, kontinuirano pratila njihovu umetničku praksu i pisala o njoj, dok je sa pojedinim učesnicima i učesnicama izložba My Art is My Reality novo profesionalno iskustvo. Posebno bih istakla romske umetnike i umetnice koji su svojim pristupima umetnosti istakli značaj kritike stereotipne predstave o Romima, dominantne u društvenoj stvarnosti, mainstream kulturi i umetnosti, te progovorili o stvarnim problemima sa kojima se svakodnevno susreću.

MT Kakvo je stanje s umjetnošću Roma unutar umjetničkoga institucionalnog sustava? Koliko je suvremena umjetnost Roma, ali i drugih marginaliziranih skupina, zapravo (ne)vidljiva unutar tzv. mainstream umjetničke scene i postoje li konkretne inicijative i/ili institucije koje rade na afirmaciji umjetnosti marginalnih skupina poput, recimo, berlinske umjetničke kolekcije Kai Dikhas?

skM Položaj romske populacije se istorijski odvija izolovano, na marginama evropskog društva, uz snažno prisustvo socijalno-političke diskriminacije. Umetnost Roma gotovo je nevidljiva u umetničkom institucionalnom sistemu i već skoro 500 godina nije valorizovana evropskim kriterijima. Ipak, postoje primeri kao što su izložba First National Exhibition of Self-Taught Roma Artists (1979, Budimpešta), ${ }^{2}$ izložba First World Exhibition of Roma Art (1985, Pariz), ${ }^{3}$ umetnička kolekcija Kai Dikhas (Berlin) koja prikuplja avangardna i savremena dela umetnika i umetnica romskog i sintskog porekla iz Evrope, Romski paviljon na Bijenalu umetnosti u Veneciji ${ }^{4}$ ili aktivnosti nezavisne fondacije European Roma Cultural Foundation, koji ukazuju na mogućnosti okupljanja, izučavanja i afirmacije savremene romske umetnosti. Ove organizacije i događaji postavljaju pitanje da li je vreme da se umetnost marginaliziranih grupa, kao što su Romi i Sinti, nađe u razvijenim muzejskim institucijama, kao i „ko upravlja sredstvima predstavljanja i ko ima moć da promoviše dominantne kulturne i moralne vrednosti u vezi s romskim zajednicama" ? ${ }^{5}$

Izložba My Art is My Reality je, osim umetnika i umetnica (i) Romskog identiteta, uključila i kustosa galerije Kai Dikhas iz Berlina Moritza Pankoka koji je za ovu priliku napisao uvodni tekst u katalogu „Snaga koja mijenja. Suvremena umjetnost Sinta i Roma". U tekstu autor potvrđuje da je istorija Sinta i Roma definisala većina, a „za većinu je uvijek bilo od koristi da pomoću manjine stvara mit o strancima, tj. sliku koja je preuzimala ulogu dežurnog krivca". ${ }^{6}$ Smatra da je u takvim procesima Sintima i Romima oduzeta mogućnost da ravnopravno učestvuju u društvu, da se obrazuju, politički samostalno zastupaju i da dobiju potrebne resurse.

U umetničkom sistemu romska umetnost se kroz istoriju tretirala kao „naivna” umetnost, čime se nije ostavljala mogućnost drugačijeg sagledavanja. Od Svetskog kongresa Roma 1971. godine, iako su politički zahtevi i dalje ostali neispunjeni, aktivnosti savremenih romskih umetnika i umetnica, čiji su individualni pristup, poznavanje formalne i sadržajne strukture, kritičke prakse, kao i medijske i intermedijske percepcije, razvili umetničku aktivnost koja narušava vladajuća viđenja o manjinskoj kulturi koja su postojala vekovima, a koja su pogrešno polazila od toga da se svim pripadnicima jedne manjine mogu pripisati iste osobine, kao i da je nivo njihovog umetničkog dometa marginalan. Namera izložbe My Art is My Reality je staviti u fokus pitanje vidljivosti umjetničke prakse Roma kao integralnog i ravnopravnog segmenta evropskog kulturnog prostora. Kroz uključivanje različitih marginalnih pozicija, naročito romske, omogućeno je kreiranje

\section{2}

Izložbu je organizovala romska aktivistkinja Ágnes Daróczi; kustos Gérard Gartner. 3 Première Mondiale d'art Tzigane, inicijatorka Sandra Jayat, umetnica i pesnikinja. 4 Prvi Romski paviljon na Bijenalu umjetnosti u Veneciji, Paradise Lost (2007), kustoskinja Tímee Junghaus, Palazzo Pisani, Santa Marin, Venecija, bilo je prvo veće predstavljanje savremene romske umetnosti na međunarodnoj sceni.

5

Drugo izdanje Romskog paviljona u Veneciji, Call the Witness (2011), kustoskog tima koji sačinjavaju Suzana Milevska, Vladan Jeremić, Rena Rädle i Enisa Eminovska, koncipirano je kroz ovo pitanje. 6

Pankok, „Snaga koja mijenja: Suvremena umjetnost Sinta i Roma", 26-27. 
dauerte am Rande der gesellschaftlichen Prozesse die Geschichte vom Leid und von der Diskriminierung der Roma an, die zu einem wesentlichen Merkmal ihrer nationalen Identität geworden ist.

Die internationale Ausstellung ist deswegen durch die Beteiligung von Künstlern, Künstlerinnen und Künstlergruppen konzipiert, die sich mit der (Re)Interpretation der Erinnerungen an die Gewalt und ihren diskursiven Ablagerungen befasst, mit der (De)Konstruktion der Erinnerung und der Projektion neuer (Mikro)Geschichten durch Versöhnung und Gemeinsamkeit sowie durch die Positionierung persönlicher fluider Identitäten im Rahmen globaler Prozesse. Die ausgewählten Künstler/-innen nutzen Fallstudien aus der Vergangenheit, Archivmaterial oder persönliche Erfahrungen als Ressource für ihre erneute Kontextualisierung und Präsentation. Das Ziel der Ausstellung ist es, auf die Bedeutung der Erinnerung an gewalttätige und traumatische Erfahrungen hinzuweisen, aber auch die Bedeutung der Versöhnung und des Erhalts der Gemeinschaft durch die zeitgenössische künstlerische Praxis und die Prüfung der Position der kollektiven und persönlichen Identität als veränderliche Kategorien, die direkt mit den gesellschaftlichen Prozessen verbunden sind.

An der Ausstellung sind Kultureinrichtungen und Einzelpersonen (Künstler/innen und Kuratoren/-innen) aus Deutschland, Frankreich, Kroatien, Serbien, Slowenien, Bosnien und Herzegowina, Mazedonien, der Slowakei, Ungarn, Kanada, etc. beteiligt. Unter den Autoren/-innen sind: das Kollektiv ISTE, das von Andreja Kulunčić ins Leben gerufen wurde und geleitet wird, Robert Jankuloski, Herlinde Koelbl, Stevan Kojić, Siniša Labrović, Leray Valérie, Monika Moteska, Branislav Nikolić, Vessna Perunovich, André Jenö Raatzsch, Emília Rigová, Selma Selman und Selman Trtovac. Im Verlauf meiner bisherigen kuratorischen und wissenschaftlichen Arbeit habe ich mit einigen von ihnen bereits zusammengearbeitet, habe ihre künstlerische Arbeit begleitet und darüber geschrieben und mit einzelnen der teilnehmenden Künstler war die Ausstellung My Art is My Reality eine neue professionelle Erfahrung. Ganz besonders möchte ich die Roma-Künstler/-innen betonen, die mit ihren künstlerischen Ansätzen die Bedeutung der Kritik an den stereotypen Vorstellungen über die Roma hervorgehoben haben, die in der gesellschaftlichen Realität, der Mainstream-Kultur und -Kunst vorherrschend sind, und über die tatsächlichen Probleme gesprochen haben, mit denen sie sich täglich auseinandersetzen müssen.

мт Wie steht es um die Kunst der Roma innerhalb des institutionellen Kunstsystems? Wie sehr ist die zeitgenössische Kunst der Roma, aber auch anderer Randgruppen im Rahmen der sog. Mainstream-Kunstszene eigentlich (un) sichtbar und gibt es konkrete Initiativen und/oder Institutionen, die an der Affirmation der Kunst von Randgruppen wie z.B. die Berliner Kunstsammlung Kai Dikhas arbeiten?

Die Roma-Bevölkerung war, historisch betrachtet, isoliert, am Rande der europäischen Gesellschaft positioniert, geprägt durch eine starke gesellschaftspolitische Diskriminierung. Die Kunst der Roma war im institutionellen System der Kunst fast unsichtbar und wurde fast 500 Jahre lang nicht nach dem Maßstab europäischer Kriterien bewertet. Dennoch gibt es Beispiele wie die First National Exhibition of Self-Taught Roma Artists (1979, Budapest); ${ }^{2}$ die Ausstellung First World Exhibition of Roma Art (1985, Paris), ${ }^{3}$ die Kunstsammlung Kai Dikhas (Berlin), die avantgardistische und zeitgenössische Werke von Künstlern mit Romaund Sinti-Hintergrund sammelt, den Roma-Pavillon auf der Kunstbiennale in Venedig ${ }^{4}$ oder die Tätigkeiten der unabhängigen European Roma Cultural Foundation, die zeigen, dass es möglich ist, zeitgenössische Roma-Kunst zusammenzubringen, zu studieren und zu affirmieren. Diese Organisationen und Veranstaltungen werfen die Frage auf, ob es nicht vielleicht an der Zeit ist,

\section{2}

Organisiert von der Roma-Aktivistin Ágnes Daróczi, Kurator: Gérard Gartner.

Première Mondiale d'art Tzigane, Initiatorin Sandra Jayat, Künstlerin und Dichterin. 4

Erster Roma-Pavillion auf der Kunstbiennale in Venedig, Paradise Lost (2007), Kuratorin Tímea Junghaus, Palazzo Pisani, Santa Marin, Venedig, war die erste größere Präsentation der zeitgenössischen Roma-Kunst auf der internationalen Szene. 


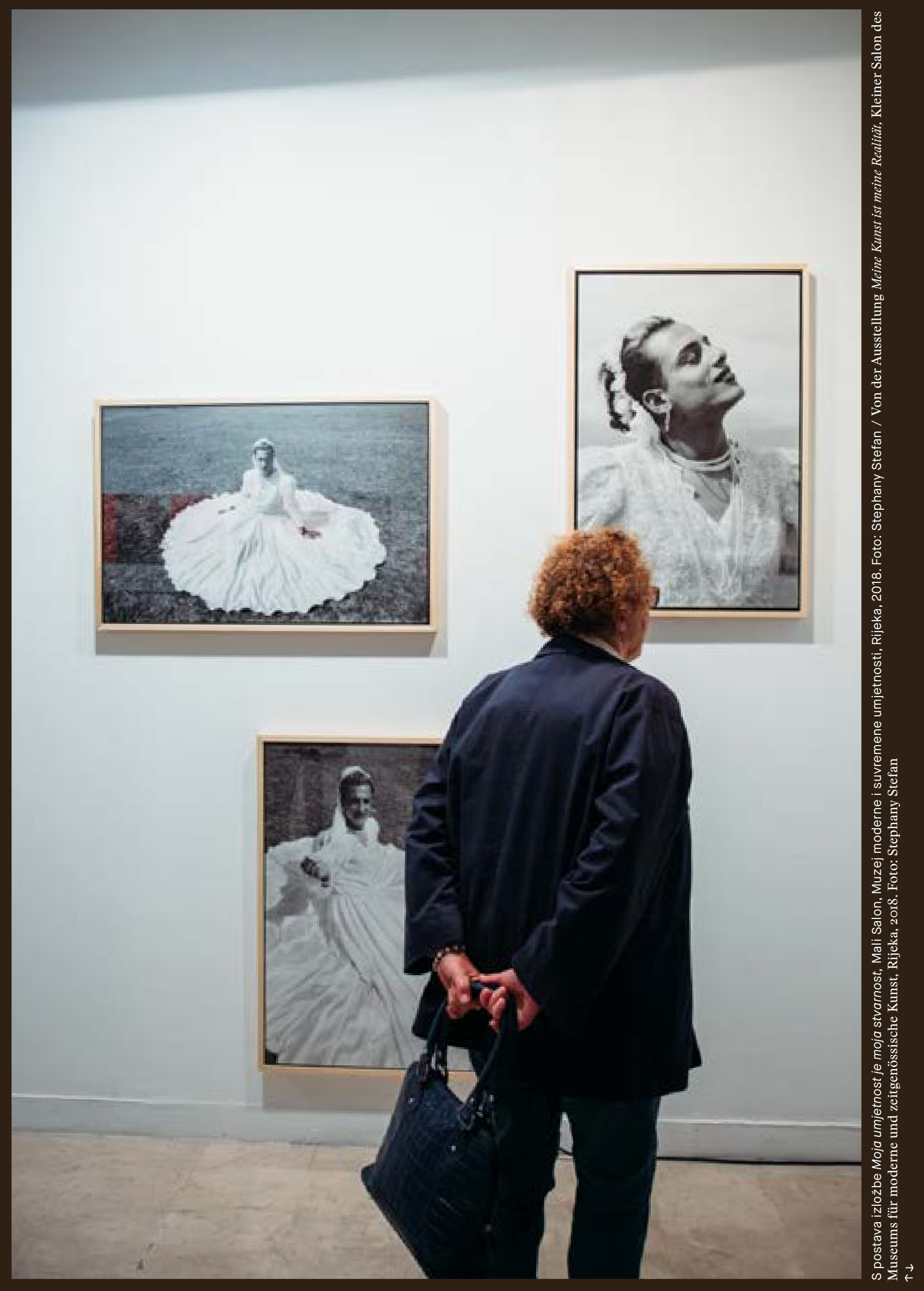




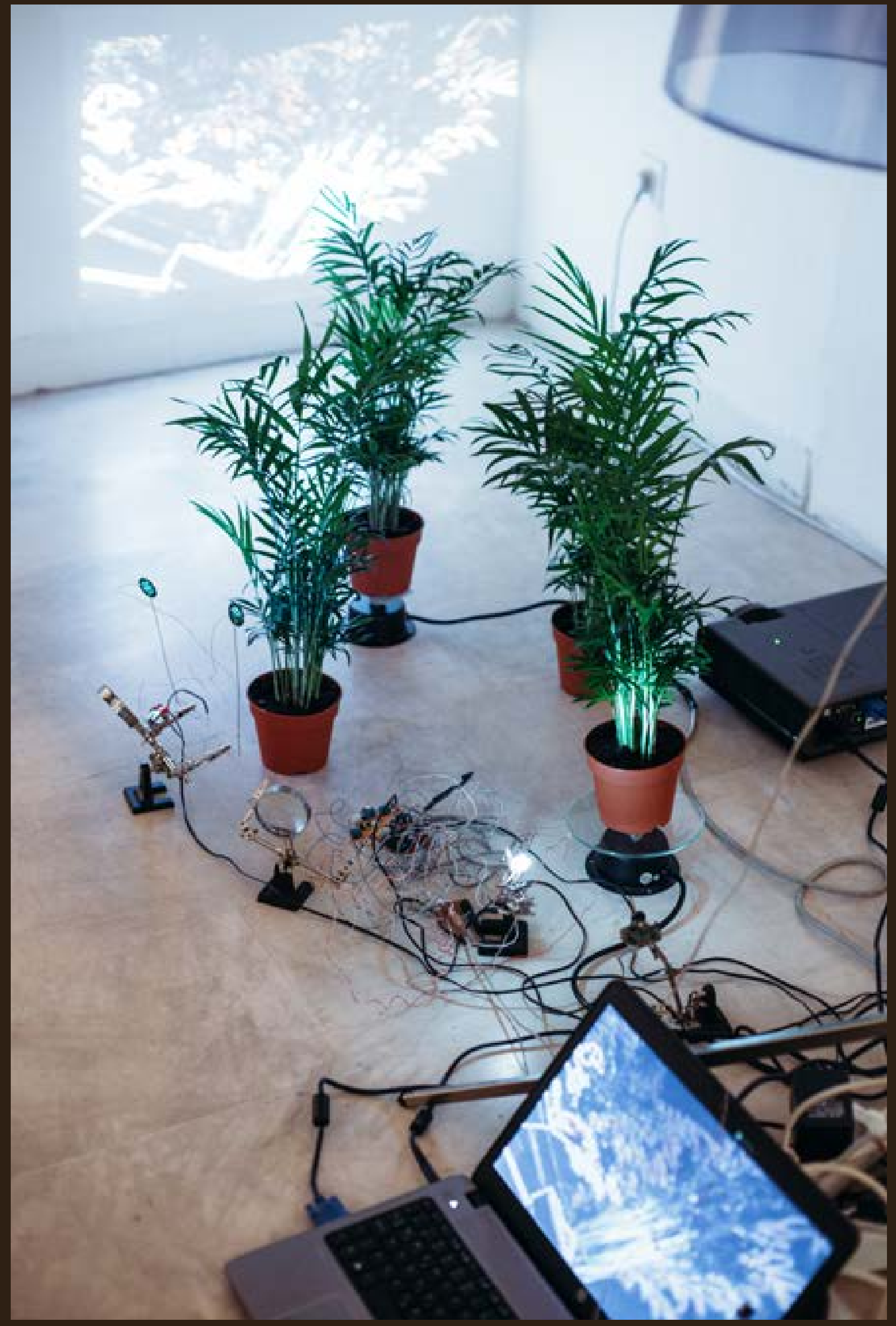


nove platforme otvorene za razmenu i komunikaciju o najrazličitijim, čak i problematičnim temama, potiskivanim i bolnim prošlostima, traumatskim nasleđima i zatvorenim odnosima.

MT Jeste li, istražujući umjetnost Roma i umjetnike romskog porijekla pri razvijanju svoga kustoskog koncepta za izložbu My Art is My Reality, dobili konkretne uvide u društvenu, političku i kulturnu situaciju Roma u Europi, u probleme s kojima se nose na svakodnevnoj razini i u eventualna mjesta njihove efikasnije integracije u društveno-kulturna i politička tkiva, a s obzirom na sve veći zamah radikalnih i ekstremnih pozicija i diskriminatornih tendencija?

sкм Umetničke radove Valérie Leray, Andréa Raatzscha, Emílie Rigove i Selme Selman predstavljene na izložbi My Art is My Reality Moritz Pankok smatra recentnom umetničkom avangardom evropskih Roma. U pitanju su radovi koji koriste jezik internacionalne savremene umetničke prakse da bi se progovorilo o problemima svog kolektivnog etničkog identiteta i ličnih negativnih iskustava prouzrokovanih biološkim poreklom. Njihova umetnička praksa kritički pristupa dominatnom društveno-umetničkom sistemu, vladajućim stereotipima prisutnim u već istorijskom načinu prikazivanja Roma u umetnosti i kulturi od strane „većine” te ispitivanju sopstvenog fluidnog identiteta. Istraživanje pozicije Roma na ovoj izložbi istovremeno je otvorilo pitanje pozicije drugih manjinskih grupa, koje se sve susreću sa napadima prouzrokovanim narastajućom popularizacijom desničarskih pokreta i ekstremnih nacionalističkih ideologija. Zato se izložba osim etničkog, bavi i problemom rodnog, seksualnog i verskog identiteta, njihovim istupanjima u javnosti te svakodnevicom pojedinaca.

Jedan od takvih primera je rad Selme Selman, umetnice koja se služi umetnošću kao sredstvom za izazivanje društvenih promena, pogotovo što se tiče večnih predrasuda i izolacije pojedinih zajednica izvan vladajućeg vrednosnog sistema. Usmerena je na propitivanje pozicije identiteta, naročito romskog i ženskog, nametnutih granica, praznoverja, stereotipa i društvene marginalizacije. Polazi od problema sopstvene zajednice i ličnog, porodičnog života obeleženog stigmom zbog romskog porekla. Na izložbi My Art is My Reality izlaže novi rad nastao kao reakcija na sukob koji je imala tokom prethodnog boravka u Rijeci, a koji je bio izazvan njenim etničkim poreklom i rodnim karakteristikama. Koristi postojeću video igru Mortal Kombat u koju poziva posetioce da se uključe i direktno obračunaju sa njezinim avatarom (avatarkom), paralelno prikazujući dokumentaciju nemilog događaja koji se proširio na društvenim mrežama. Teži dekonstrukciji tradicionalnog, diskriminatornog i objektivizirajućeg pogleda na žensko, pogotovo romsko, telo.

MT Na koji način pojedini radovi prikazani na izložbi reinterpretiraju sjećanja na nasilnu prošlost i ratne sukobe te njihove utjecaje na formiranje marginalnih identiteta u današnjici? Možemo li reći da grupna izložba My Art is My Reality nosi dokumentaristički i/ili edukativni potencijal i ako da, u kojim segmentima?

sкM Izložba My Art is My Reality bavi se konceptualizacijom istorije sećanja, ispitivanjem moći arhiviranja i kolekcioniranja te (de)konstrukcijom marginalnih pojava kroz osobni, autorski pristup i propitivanje vlastite pozicije unutar diskurzivnih istorijskih taloga.

Umetnik, kustos i romski aktivist André Jenö Raatzsch kroz različite umetničke aktivnosti, kao i analizom arhivske dokumentacije i građe, istražuje pozicije Roma u društvu i mesta romskog identiteta kroz istoriju. U video radu Sostar, Sostar, miert vagy te Sostar? (2014) propituje poziciju vlastitog fluidnog identiteta koji počiva na promenljivosti mesta života, društvenih kretanja i međuljudskih odnosa. Jesam li Mađar, Rom, Nemac ili Evropljanin, pita se. Kritički ispituje proces samoizgradnje u savremenog umetnika i sagledava vlastitu poziciju na aktualnoj umetničkoj sceni, kao i mogućnosti napredovanja i prepoznavanja. To ga je 
dass die Kunst von Randgruppen, wie beispielsweise der Roma und Sinti in entwickelte Museumseinrichtungen Einzug finden sowie wer „die Mittel verwaltet und die Macht hat, dominante kulturelle und moralische Werte in Bezug auf die Roma-Gemeinschaften zu fördern?" 5

An der Ausstellung My Art is My Reality war außer den Künstlern/innen (unter anderem auch) mit Roma-Identität auch der Kurator der Galerie Kai Dikhas aus Berlin, Moritz Pankok, beteiligt, der für diese Gelegenheit den einleitenden Text für den Katalog „Transforming Powers. The contemporary Art of Sinti and Roma” geschrieben hat. In diesem Text bestätigt der Autor, dass die Geschichte der Sinti und Roma von der Mehrheit geschrieben wurde und „der Mehrheit war es stets hilfreich, mit der Minderheit die Konstruktion von Fremden, also eine Projektionsfläche herzustellen, die die Rolle des Sündenbocks übernahm”. Er ist der Ansicht, dass durch solche Vorgehensweisen, den Sinti und Roma die Möglichkeit verwehrt wurde, Zugang zur gesellschaftlichen Teilhabe, zu Bildung, zu politischer Selbstvertretung und den notwendigen Ressourcen zu bekommen.

Im Kunstsystem wurde die Kunst der Roma durch die Geschichte hindurch als „naive” Kunst behandelt, wodurch keine Möglichkeit bestand, sie anders zu betrachten. Seit dem Welt-Roma Kongress I97I, obwohl die politischen Forderungen auch weiterhin nicht erfüllt sind, haben die Aktivitäten der zeitgenössischen RomaKünstlerInnen, ihr individueller Ansatz, das Kennen der formalen und inhaltlichen Struktur, die kritische Praxis sowie die mediale und intermediale Wahrnehmung eine künstlerische Aktivität entwickelt, die die vorherrschenden Einstellungen über eine Minderheitenkultur, die seit Jahrhunderten bestanden und fälschlicherweise davon ausgingen, dass allen Angehörigen einer Minderheit die gleichen Eigenschaften zugeschrieben können und dass das Niveau ihrer künstlerischen Reichweite marginal ist, ins Wanken gebracht. Die Absicht der Ausstellung My Art is My Reality war es die Frage der Sichtbarkeit der künstlerischen Praxis der Roma als integralen und gleichberechtigten Bestandteil des europäischen Kulturraums in den Fokus zu stellen. Durch die Einbeziehung unterschiedlicher Randpositionen, vor allem der Roma, wurde die Schaffung einer neuen Plattform zum Austausch und zur Kommunikation über die unterschiedlichsten, ja sogar problematischen Themen, über unterdrückte und schmerzende Vergangenheiten, das traumatische Erbe und geschlossenen Beziehungen ermöglicht.

мт Haben Sie bei der Erforschung der Roma-Kunst und Künstler mit Roma-Hintergrund und bei der Entwicklung Ihres kuratorischen Konzeptes für die Ausstellung My Art is My Reality konkrete Einblicke in die gesellschaftliche, politische und kulturelle Situation der Roma in Europa, in die Probleme gewonnen, mit denen sie sich tägliche auseinandersetzen müssen und in eventuelle Orte ihrer effektiveren Integration in das soziale, kulturelle und politische Gewebe, angesichts der immer stärker werdenden radikalen und extremistischen Positionen und diskriminatorischen Tendenzen?

sкм Moritz Pankok ist der Ansicht, dass die auf der Ausstellung My Art is My Reality präsentierten Kunstwerke von Valérie Leray, André Raatzsch, Emília Rigova und Selma Selman die aktuelle künstlerische Avantgarde der europäischen Roma darstellen. Es handelt sich dabei um Werke, die die Sprache der internationalen zeitgenössischen Kunst nutzen, um die Probleme ihrer kollektiven ethnischen Identität und die durch ihre biologische Herkunft verursachten persönlichen negativen Erfahrungen darzustellen. Ihre Werke hinterfragen kritisch das dominante gesellschaftliche und künstlerische System, die herrschenden Stereotype, die bereits in der historischen Art der Darstellung der Roma in der Kunst und Kultur durch die „Mehrheit” anwesend sind, und die Erforschung ihrer eigenen fluiden Identität. Die Erforschung der Stellung der Roma bei dieser Ausstellung hat gleichzeitig auch die Frage nach der Stellung anderer Minderheiten geöffnet, die sich durch die anwachsende Popularität rechtsorientierter Bewegungen und
5 Dem Konzept der zweiten Ausgabe des Roma Pavillons in Venedig, Call the Witness (20II), des Kuratorenteams: Suzana Milevska, Vladan Jeremić, Rena Redle und Enisa Eminovska, lag diese Frage zugrunde.

Pankok, „Transforming Powers. The contemporary Art of Sinti and Roma", 26-27. 
navelo da 2012. godine osnuje The Roma Image Studio, platformu za razvoj i praćenje angažovane umetnosti u Berlinu, a 2013. umetničku grupu Sostar? / Why? \{roma\}, u okviru koje se nastavio baviti konceptualnom i kritičkom umetničkom praksom Roma.

U konceptualnom radu Instant porodice_multiplikacija ljubavi (2018) Robert Jankuloski istražuje aktualni društveni kontekst Skoplja, grada u kojem živi i radi, a koji je kulturološki primer, a ujedno i žrtva posledica tranzicionih procesa započetih raspadom Jugoslavije i formiranjem samostalnih zajednica i država, s problematičnim pitanjem identiteta. Savremenom umetničkom fotografijom Robert Jankuloski beleži scenografiju skopskog javnog prostora u kojem pojedini objekti i zgrade izgledaju kao makete, kompjuterski ubačene u kompoziciju, s lažnim privremenim fasadama i skulpturama. Autor koristi manipulativne mogućnosti novih tehnologija u fotografiji i metodu insceniranja, smeštajući ljude (lažne porodice) u nepripadajući ambijent kako bi preispitao odnos istinitog i lažnog u umetnosti i društvenoj stvarnosti te mesta čoveka i porodice u njima.

Monika Moteska kroz seriju crno-belih fotografija Forever Yours, Elvira (20012018), realizovanih u ruralnom makedonskom pejzažu, pristupa izgradnji specifičnog odnosa s izabranim modelom, Elvirom, Romom transseksualnog identiteta koji sanja da postane nevesta, a čiju želju na trenutak ispunjava autorka zabeleženim fotografijama. Problem etničke, verske, rasne, rodne i seksualne diskriminacije prisutan je i u ovom radu kao nerešiv društveni problem, kojeg su svesni i model i umetnica. Kroz medij fotografije Monika Moteska poigrava se klasičnom ikonografijom svadbenih portreta, svakodnevne slike društvene stvarnosti, nudeći prikaz mogućeg, drugačijeg pristupa te ističući važnost promene društvene svesti u prihvatanju različitosti.

Stevan Kojić ne razmišljajući o tradicionalnim granicama postavljenim između različitih medija i tehnika, ispituje aktualna društvena pitanja koristeći savremena tehničko-tehnološka dostignuća, audio-vizualne, digitalne i elektronske medije. U svom umetničkom projektu Samoodrživi sistem apsurda (2010-2018) bavi se savremenim temama, kao što su ekologija, iskorišćavanje prirodnih resursa, genetska modifikacija, robotika i stvaranje samoodrživih sistema, ali i pitanjima privatnih i javnih odnosa, problema percepcije sadržaja i promenljivosti informacija. Kreira specifične eko-tehnološke sisteme da bi naglasio primarnu ideju projekta-apsurdnost pojedinih društvenih odnosa, posebno ekonomije i ekologije.

Umetnički radovi govore o različitim problemima, prouzrokovanim konfliktnim društvenim odnosima, ratovima, razarajućim procesima, narušenom prirodnom i urbanom sredinom te društveno neprihvatljivim politikama identiteta. Pojedinačna istraživanja svakog od njih mogu poslužiti kao prikaz savremenog društva i kao takva biti deo dokumentarističkog i edukativnog procesa saznanja.

MT Na koji način radovi komuniciraju s publikom? Pitanje se djelomično referira i na činjenicu da je izložba postavljena u Malom salonu, galerijskom prostoru MMSU-a smještenom na najfrekventnijem gradskom mjestu, riječkom Korzu, a čime se, na neki način, tema koja progovara o društvenim nepravdama, isključivanjima i potlačenosti stavlja u centar pozornosti. Treba li umjetnost izaći iz galerija, odnosno muzeja, a da bi izazvala konkretne reakcije i/ili potaknula na razmišljanje-poput, recimo, rada Andreje Kulunčić i kolektiva ISTE koji je izlagan na javnim gradskim mjestima poput billboarda na autobusnim stanicama, city light boksova i sličnim?

SKM Kolektiv ISTE koji je inicirala i vodi Andreja Kulunčić, a koji čini grupa žena iz Zagreba različitih etničkih, verskih, rasnih i seksualnih identiteta, svojim aktivnostima žele upozoriti javnost na prisutnost diskriminacije u hrvatskom društvu te ukazati na važnost prihvatanja različitosti, služeći se pri tome javnim prostorom 
extremer nationalistischer Ideologien verursachten Angriffen gegenüber sehen. Deswegen befasst sich die Ausstellung außer mit der ethnischen auch mit den Problemen der geschlechtsspezifischen, sexuellen und religiösen Identität, ihren Auftritten in der Öffentlichkeit und dem Alltag des Einzelnen.

Ein solches Beispiel ist die Arbeit von Selma Selman, einer Künstlerin, die die Kunst als Werkzeug nutzt, um gesellschaftliche Veränderungen hervorzurufen, vor allem in Bezug auf die ewigen Vorurteile und die Isolation einzelner Gemeinschaften außerhalb des vorherrschenden Wertesystems. Sie hinterfragt die Stellung der Identität, vor allem der Identität als Roma und Frau, der aufgezwungenen Grenzen, des Aberglaubens, der Stereotype und der gesellschaftlichen Marginalisierung, ausgehend vom Problem der eigenen Gemeinschaft und des eigenen Familienlebens geprägt durch das Stigma ihrer Roma-Herkunft. Auf der Ausstellung My Art is My Reality stellt sie ihre neue Arbeit vor, die als Reaktion auf den Konflikt entstand, den sie während ihres vorhergehenden Aufenthalts in Rijeka hatte, der durch ihre ethnische Herkunft und ihr Geschlecht bedingt war. Mithilfe des Video-Spiels Mortal Kombat fordert sie die Besucher auf, sich zu beteiligen und direkt mit ihrem Avatar (Avatarin) abzurechnen, und zeigt parallel dazu die Dokumentation des unschönen Ereignisses, das sich über die sozialen Netze verbreitet hat. Sie strebt nach der Dekonstruktion der traditionellen, diskriminierenden Betrachtungsweise des weiblichen Körpers, vor allem des weiblichen Roma-Körpers, die ihn zu einem Objekt macht.

мт Wie reinterpretieren die einzelnen auf der Ausstellung präsentierten Arbeiten die Erinnerungen an die gewalttätige Vergangenheit und kriegerischen Auseinandersetzung sowie ihre Auswirkungen auf die Gestaltung der Randidentitäten in der heutigen Zeit? Kann man sagen, dass die Gruppenausstellung My Art is My Reality in sich auch ein dokumentaristisches und/oder erzieherisches Potenzial birgt und wenn ja, in welchen Segmenten?

sкм Die Ausstellung My Art is My Reality befasst sich mit der Konzeptualisierung der Geschichte der Erinnerungen, der Macht der Archivierung und Sammlung sowie dem (De-) Konstruieren von Randphänomen durch einen persönlichen Ansatz der Autoren und Hinterfragung der eigenen Position innerhalb der diskursiven historischen Ablagerungen.

Der Künstler, Kurator und Roma-Aktivist André Jenö Raatzsch beschäftigt sich durch verschiedene künstlerische Aktivitäten mit der Erforschung der Stellung der Roma in der Gesellschaft und dem Ort der Roma-Identität durch die Geschichte. In der Videoarbeit Sostar, Sostar, miert vagy te Sostar? (2014) hinterfragt er die Position der eigenen fluiden Identität, die auf der Veränderlichkeit des Lebensortes, der sozialen Bewegungen und der persönlichen Beziehungen basiert. Bin ich Ungar, Roma, Deutscher oder Europäer, fragt er sich. Kritisch betrachtet er den Prozess der eigenen Entwicklung zum zeitgenössischen Künstler und seine Position innerhalb der aktuellen Kunstszene sowie die Möglichkeiten für eine Karriere und Anerkennung. Das hat ihn dazu angeregt 2012 The Roma Image Studio, eine Plattform zur Entwicklung und Verfolgung engagierter Kunst in Berlin und 20I3 die Künstlergruppe Sostar? / Why? \{roma\} zu gründen, in deren Rahmen er sich auch weiterhin mit der konzeptuellen und kritischen Kunstpraxis der Roma befasst.

Robert Jankuloski untersucht in seiner konzeptuellen Arbeit Instant porodice_multiplikacija ljubavi [Instant Families_Multiplikation der Liebe] (20I8) den aktuellen gesellschaftlichen Kontext von Skopje, der Stadt, in der er lebt und arbeitet, die ein kulturologisches Beispiel und zugleich Opfer der durch den Zerfall Jugoslawiens und der Bildung selbständiger Gemeinschaften / Staaten eingetretenen Transformationsprozesse mit der problematischen Frage nach der Identität ist. Robert Jankuloski zeichnet mit zeitgenössischer Kunstfotografie 

kao metodološkom praksom. U projektu ISTE-za prihvaćanje različitosti (2017) predstavljenom na izložbi, materijal čini serija plakata i billboarda postavljena u javnom prostoru na mestima medijskog oglašavanja, kao i animacija na YouTube kanalu, proširena putem društvenih mreža. Cilj rada je da se nepravda koja je prisutna u društvu, a koju direktno osećaju učesnice projekta, iznese u javnost kako bi se učinila vidljivijom te kako bi se podstakla promena društvene svesti i društvo senzibiliziralo u odnosu prema ženama iz različitih manjinskih, marginalnih grupa. U ovom primeru je jedna tabu tema iz prostora doma izašla u prostor galerije, a zatim i u javni prostor, prostor ulice i elektronskih medija, ne samo kao problem pojedinca/pojedinke već kao simptom društva.

Osim ovog, i ostali izloženi umetnički radovi teže komunikaciji sa javnošću, što prostor kao što je Mali salon omogućava. Probleme društvenih nepravdi, diskriminacije i marginalizacije, na koje se reaguje u okviru intelektualnih i naučnih krugova, važno je učiniti vidljivim široj publici, te je direktna društvena kritika, izneta u javnom prostoru, od velikog značaja. Primer toga je i performans Ubij Cigana! (2015) Siniše Labrovića izveden u centru Zagreba u jeku predizborne kampanje. U njemu je pored autora učestvovala grupa od dvadesetak Roma koji su zajedno izveli svojevrstan „muzičko-skandirajući performans” uputivši oštru kritiku društvu koje počiva na etničkom modelu identiteta, koji postaje paradigma za isključivanje i diskriminaciju drugih i drugačijih. Autor je problematizovao poziciju nacionalnog identiteta koji se manifestuje kroz nacionalizam, rasizam i fašizam, a u čijoj izgradnji smatra da učestvuju crkva i državne institucije, koje nacionalizam koriste za opravdavanje i legitimaciju pojedinih akcija političkih snaga na vlasti. Izbor vremena, mesta, učesnika, pesama i parola koje su korištene za vreme performansa nije bio slučajan, već je njihov cilj bio direktni poziv na osvešćivanje javnosti; ovaj performans na izložbi My Art is My Reality prikazan je kroz umetničku dokumentaciju.

MT Jedan od fokusa izložbe jesu i migracije. Jedna od umjetnica na izložbi koja se bavi ovom temom je Vessna Perunovich koja se kroz svoj rad Odlazak/Preko zida (2017.) bavi geopolitičkim granicama i zidovima, ali i osobnim iskustvom migriranja. Na koji način Vessna Perunovich spaja ove dvije dimenzije-osobnu i političku-u cjelinu? Također, u kontekstu migracija povezali ste ovu izložbu s europskim projektom Risk Change, a kroz radove dvojice umjetnika na izložbiBranislava Nikolića i Selmana Trtovca. Možete li reći nešto više o ovoj odluci?

Skм Vessna Perunovich svoju intermedijsku umetničku praksu, koju razvija boraveći na različitim lokacijama, usmerava na propitivanje problema koje stvaraju geopolitičke granice i zidovi, zatvorenost i ksenofobičnost društva, pozicije imigranata u novoj sredini, njihove svakodnevne teškoće u komunikaciji i prilagođavanju, prihvatanju i usvajanju novog okruženja. Podstaknuta je političkim i ekonomskim, ali i ličnim i porodičnim razlozima, budući da je i sama iskusila ovakvu vrstu rizika. Video rad Odlazak/Preko zida (2017), realizovan za vreme rezidencijalnog programa na Malti, istražuje pitanje doma i neizvesnosti koje nosi promena životne sredine, kao i osećaje nesigurnosti, otuđenosti i izolacije karakteristične kako za migrante tako i za pripadnike i pripadnice drugih marginalnih grupa. Video beleži intimni odnos autorke prema novom okruženju, simboličnom rajskom vrtu okruženom visokim zidom koji pokušava da preskoči.

Video rad ove autorke, kao i radovi Branislava Nikolića i Selmana Trtovca, čine deo rezidencijalnih programa međunarodnog EU projekta Risk Change, u kojem Muzej moderne i suvremene umjetnosti u Rijeci i Muzej savremene umetnosti Vojvodine u Novom Sadu, iz kojeg ja dolazim, zajednički učestvuju. Tako da je na neki način projekat Risk Change, usmeren na ispitivanje migracije, bio još jedna spona izložbe My Art is My Reality i njenih aktera. Odabrani autori / autorke su tokom svojih boravaka u novim sredinama istraživali migraciju, promenu, rizik, ali i poziciju specifičnosti mesta i svog identiteta u njemu. 
die Szenerie des öffentlichen Raums von Skopje auf, in dem einzelne Gebäude wie Modelle aussehen, die mittels Rechner in die Komposition integriert wurden, mit falschen vorläufigen Fassaden und Skulpturen. Der Autor nutzt die manipulativen Möglichkeiten der neuen Technologie in der Fotografie und die Inszenierungsmethode, indem er Menschen (falsche Familien) in eine ihnen nicht entsprechende Umgebung versetzt, um die Beziehung zwischen wahr und falsch in der Kunst und der gesellschaftlichen Realität sowie die Position von Mensch und Familie darin zu untersuchen.

Monika Moteska zeigt anhand einer Reihe von Schwarz-Weiß-Fotografien Forever Yours, Elvira (200I/20I8), die in der ländlichen mazedonischen Landschaft aufgenommen wurden, die Entwicklung einer gewissen Koexistenz mit dem ausgewählten Modell, Elvira, einem transsexuellen Roma, der davon träumt, Braut zu werden und dessen Wunsch die Autorin mit den aufgenommenen Fotos für einen Augenblick erfüllt. Das Problem ethnischer, religiöser, rassistischer, geschlechtsspezifischer und sexueller Diskriminierung ist auch in diesem Werk als ein unlösbares soziales Problem präsent, dessen sich sowohl das Modell als auch die Künstlerin bewusst sind. Mithilfe der Fotografie spielt Monika Moteska mit der klassischen Ikonografie von Hochzeitsporträts, dem täglichen Bild gesellschaftlicher Realität und bietet die Darstellung eines möglichen, anderen Ansatzes sowie die Bedeutung der Veränderung des sozialen Bewusstseins zur Akzeptanz von Unterschiedlichkeiten.

Stevan Kojić untersucht, ohne die traditionellen Grenzen zwischen verschiedenen Medien und Techniken zu berücksichtigen, aktuelle gesellschaftliche Probleme anhand moderner technischer und technologischer Errungenschaften, audiovisueller, digitaler und elektronischer Medien. In seinem Kunstprojekt Samoodrživi sistem apsurda [Selbsterhaltendes System des Absurds] (20IO-20I8) befasst er sich mit aktuellen Themen wie: Ökologie, Nutzung natürlicher Ressourcen, Gentechnologie, Robotik und Gestaltung von sich selbst erhaltenden Systemen, aber auch mit Fragen privater und öffentlicher Beziehungen, dem Problem der inhaltlichen Wahrnehmung und Variabilität von Informationen. Er schafft spezifische öko- und technologische Systeme, um die primäre Idee des Projekts - die Absurdität bestimmter sozialer Beziehungen, vor allem der Wirtschaft und der Ökologie — zu betonen.

Die Kunstwerke artikulieren unterschiedliche Probleme, die durch die konfliktträchtigen sozialen Beziehungen, Kriege, Zerstörungsprozesse, das gestörte Gleichgewicht der Natur und der Stadt sowie durch sozial inakzeptable Identitätspolitiken verursacht wurden. Die einzelnen Forschungsarbeiten jedes von ihnen können als Darstellung der zeitgenössischen Gesellschaft dienen und als solche Teil eines dokumentaristischen und Erziehungsprozesses der Erkenntnis sein.

мт Wie kommunizieren die Arbeiten mit dem Publikum? Die Frage bezieht sich auch teilweise auf die Tatsache, dass die Ausstellung im Kleinen Salon, dem Galeriebereich des Museums für moderne und zeitgenössische Kunst stattfindet, das sich auf dem Korzo von Rijeka befindet, dem frequentesten Ort in der Stadt, wodurch in gewisser Weise das Thema, das sich mit gesellschaftlichen Ungerechtigkeiten, Ausschlüssen und Unterdrückung befasst, in den Mittelpunkt gestellt wird. Muss die Kunst aus den Galerien bzw. Museen herauskommen, um konkrete Reaktionen hervorzurufen und/oder zum Nachdenken anzuregen - wie z.B. die Arbeit von Andreja Kulunčić und dem Kollektiv ISTE (Gleichwertige), die an öffentlichen Orten wie z.B. Billboards an Bushaltestellen, City-light-Boxen u.ä. ausgestellt wurde?

sкm Das Kolletiv ISTE (Gleichwertige), das von Andreja Kulunčić initiiert wurde und geführt wird, ist eine Gruppe von Frauen aus Zagreb mit verschiedenen 
Selman Trtovac u radu Riječka linija (2018) nastavio je da se bavi svojom ključnom temom-kontekstualizacijom linije, kao simboličke ideje i vodilje, kako u vremenskom, tako i u prostornom smislu. Dvadeset sedam godina nakon poslednje posete Rijeci autor se vratio u ovaj grad, u okviru rezidencijalnog programa, i realizovao video rad kao svojevrsni performans u kojem noseći svog sina hoda od bivše do sadašnje lokacije Muzeja moderne i suvremene umjetnosti, u kojem je poslednji put izlagao na Bijenalu mladih 1991. godine. Ovim činom simbolično je povukao liniju, odnosno dao značaj vremenskom i prostornom povezivanju važnom kako iz lične, generacijske, tako i iz opšte perspektive rata u bivšoj Jugoslaviji i neizbežne migracije stanovništva. Drugi segment rada čini crtež velikog formata, blizak njegovoj prethodnoj seriji radova, tzv. energetskih linija u kojima autor kroz upotrebu grafita na papiru, ali i vlastite krvi, naglašava koncept i istraživanje o pitanjima odnosa tela i crteža, linije i prostora, vremena i energije, ali i kretanja duhovne životne sile i vodilje.

Branislav Nikolić svoj umetnički koncept gradi kroz primenu specifične metodologije sakupljanja i recikliranja otpadnog materijala, principa bliskog onom koji se primenjuje pri izgradnji privremenih romskih naselja. Svojevrsne kolažne in situ ili situirane objekte i instalacije, sastavljene kombinacijom različitog raznobojnog, trošnog i odbačenog materijala, razvija u seriji svojih radova pod zajedničkim nazivom Sekundarna arhitektura, koju realizuje u mnogim izložbenim i alternativnim prostorima. Kao projekat nastao tokom rezidencijalnog boravka u Rijeci izvedena je Ispovjedaonica (2018), prema inicijalnoj ideji Hermanna Glettlera, austrijskog savremenog umetnika i sadašnjeg biskupa u Innsbrucku, takođe od sekundarnih sirovina i u dijalogu sa stanovnicima romskih naselja. Umetnički rad koji istovremeno može biti i sakralni objekat, ukazuje na potrebu marginalizovanih i diskriminiranih društvenih grupa za ostvarivanjem sopstvenih prava na jednakost.

MT Jedan od kritički snažnijih radova jest svakako rad Vomite, ergo sum! slovačke umjetnice Emílie Rigove čijim nazivom aludira na Descartesovu izreku „Cogito, ergo sum”, odnosno „Mislim, dakle jesam”. Rigová se kroz svoj rad referira na aproprijaciju romskog tijela kroz povijest europske kulture u kontekstu unutarnje i vanjske izgradnje romskog identiteta. Na što točno autorica upozorava kada govorimo o navedenim pitanjima? Ima li se na umu kulturna aproprijacija i prakse prezentiranja romske umjetnosti, tko uopće stvara kulturu Roma i koliko je glas potlačenih glasan ako je prezentiran kroz okulus institucionalne umjetnosti?

skM Emília Rigová svojom intermedijskom umetničkom praksom usmerena je na dekonstrukciju kulturnih i društvenih stereotipa, kao i na propitivanje politike tela, naročito romskog tela i identiteta u evropskom kulturno-istorijskom diskursu. Video radom Vomite, ergo sum! (2018) i serijom fotografija Keres Kultúra? (2018) nastavlja sa istraživanjem načina izgradnje romskog identiteta i pozicije romskog tela polazeći od lične perspektive koju stavlja u širi društveni kontekst. Propituje društvenu moć predstavljanja, promovisanja i vrednovanja romske kulture i njene pozicije u društvu. Ko ima moć da se time bavi i o tome odlučuje, neka su od pitanja koje autorka postavlja dok se pojavljuje na portretima sa zlatnim zubima ili dok iz svog tela izbacuje zlato. Tekst koji prati foto-instalaciju Keres Kultúra? dolazi iz romskog jezika i znači: „Stvaramo li kulturu?”. „Povraćanje je ovdje metafora pozicije Roma i načina na koji ih društvo gleda", 7 smatra autorica. Svojom reprezentacijom kritički analizira prevlađujuću romantizovanu poziciju Romkinje u mainstream kulturi, umetnosti i društvu, ukazujući na površnost pogleda javnosti i potrebu za novim, osvešćenim sagledavanjem. „S obzirom na dominaciju zapadnjačko-bjelačkog pisanja povijesti i na činjenicu da je romska kultura dosad, u najboljem slučaju, arhivirana samo u etnološkim zbirkama," ${ }^{8}$ pojava umetnika i umetnica koji kritički pristupaju dosadašnjem vladajućem pogledu $\mathrm{u}$ istoriji umetnosti, muzeologiji i savremenoj umetničkoj praksi, čini važan segment institucionalne kritike koji može pružiti novi pogled i pokrenuti nova pitanja i probleme.

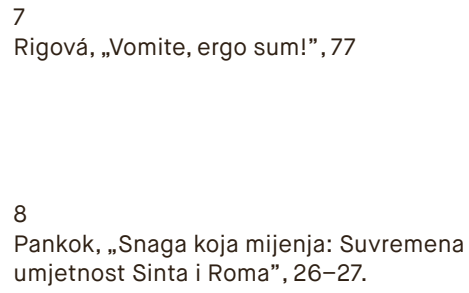
8

Pankok, „Snaga koja mijenja: Suvremena umjetnost Sinta i Roma", 26-27. 
ethnischen, religiösen, rassischen und sexuellen Identitäten, die mit ihren Aktivitäten die Öffentlichkeit auf die Diskriminierung in der kroatischen Gesellschaft aufmerksam machen und auf die Bedeutung hinweisen möchte, dass Unterschiedlichkeiten akzeptiert werden und dabei bedienen sie sich des öffentlichen Raums als methodischer Praxis. Das Material für das Projekt ISTE - za prihvaćanje razlicititosti (2OI7) [GLEICHWERTIGE-für die Akzeptanz von Unterschiedlichkeiten], das bei der Ausstellung vorgestellt wurde, setzt sich aus einer Reihe von Plakaten und Billboards im öffentlichen Raum sowie YouTubeAnimationen zusammen, die auch in den sozialen Netzwerken verbreitet werden. Das Ziel der Arbeit ist es, die in der Gesellschaft anwesende Ungerechtigkeit, die die Projektteilnehmerinnen direkt spüren, an die Öffentlichkeit heranzutragen, um sie sichtbarer zu machen und um den gesellschaftlichen Bewusstseinswandel zu fördern und die Gesellschaft für das Verhalten gegenüber Frauen aus verschiedenen Minderheits- und Randgruppen zu sensibilisieren. In diesem Beispiel ist ein Tabu-Thema aus den eigenen vier Wänden in den Galeriebereich vorgedrungen und dann auch in den öffentlichen Raum der Straße und der elektronischen Medien, nicht nur als Problem einer Einzelperson, sondern als gesellschaftliches Symptom.

Aber auch die anderen Kunstwerke streben nach Kommunikation mit der Öffentlichkeit, was ein Raum wie der Kleine Salon ermöglicht. Es ist wichtig, dass das Problem der gesellschaftlichen Ungerechtigkeit, der Diskriminierung und Marginalisierung, auf das man in den intellektuellen und wissenschaftlichen Kreisen reagiert, für die breite Öffentlichkeit sichtbar gemacht wird und eine direkte gesellschaftliche Kritik, die im öffentlichen Raum kund gemacht wird, ist von großer Bedeutung. Ein Beispiel dafür ist auch die Performacne Ubij Cigana! [Töte den Zigeuner!] (20I5) von Siniša Labrović, die während des Wahlkampfs im Zentrum von Zagreb realisiert wurde. An dieser Performance war außer dem Autor auch eine Gruppe von etwa zwanzig Roma beteiligt, die gemeinsam eine Art „musikalischer und skandierender Performance” ausgeführt und so scharfe Kritik an einer Gesellschaft geäußert haben, die auf dem ethnischen Modell der Identität basiert, das zum Paradigma der Ausgrenzung und Diskriminierung Anderer und Andersartiger wird. Der Autor hinterfragt die Position der nationalen Identität, die sich durch Nationalismus, Rassismus und Faschismus manifestiert und an deren Aufbau seiner Ansicht nach die Kirche und die staatlichen Institutionen beteiligt sind, die den Nationalismus zur Rechtfertigung und Legitimierung bestimmter Handlungen der Macht habenden politischen Kräfte nutzen. Die Zeit, der Ort, die Teilnehmer, die Lieder und Parolen, die während der Performance genutzt wurden, waren nicht zufällig gewählt, sondern ihr Ziel war ein direkter Aufruf an die Öffentlichkeit, sich dessen bewusst zu werden. Diese Performance wurde auf der Ausstellung My Art is My Reality mittels künstlerischer Dokumentation dargestellt.

мт Auch Migrationen stehen im Fokus der Ausstellung. Eine der Künstlerinnen auf dieser Ausstellung, die sich mit diesem Thema befasst, ist Vessna Perunovich, die in ihrer Arbeit Odlazak/Preko zida [Abstieg/Über die Mauer] (20I7) geopolitische Grenzen und Mauern, aber auch ihre persönliche Migrationserfahrung behandelt. Wie verknüpft Vessna Perunovich diese zwei Dimensionen-die persönliche und politische - zu einer Einheit? Im Kontext der Migration haben Sie diese Ausstellung auch mit dem europäischen Projekt Risk Change verbunden, und zwar durch die Werke zwei Künstler dieser Ausstellung_Branislav Nikolić und Selman Trtovac. Können Sie mir etwas mehr zu dieser Entscheidung sagen?

sкм Vessna Perunovich konzentriert sich mit ihrer intermedialen künstlerischen Praxis, die sie entwickelt, während sie sich an unterschiedlichen Orten aufhält, auf die Hinterfragung der Probleme, die die geopolitischen Grenzen und Mauern, die Abschottung und Fremdenfeindlichkeit der Gesellschaft, die Position von Immigranten in der neuen Umgebung schaffen, aber auch ihre täglichen Kommunikations- und Anpassungsschwierigkeiten sowie die Probleme mit der 


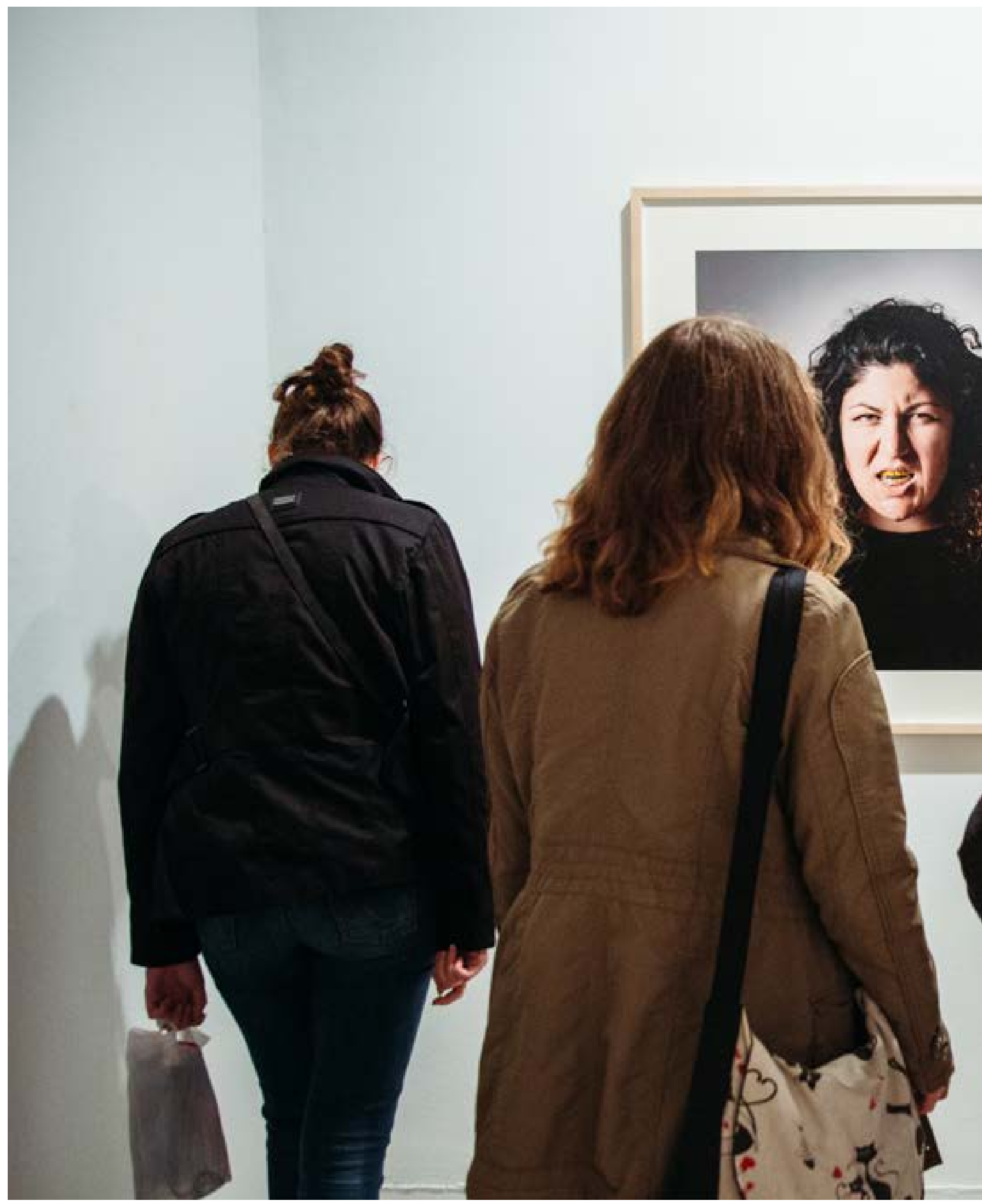




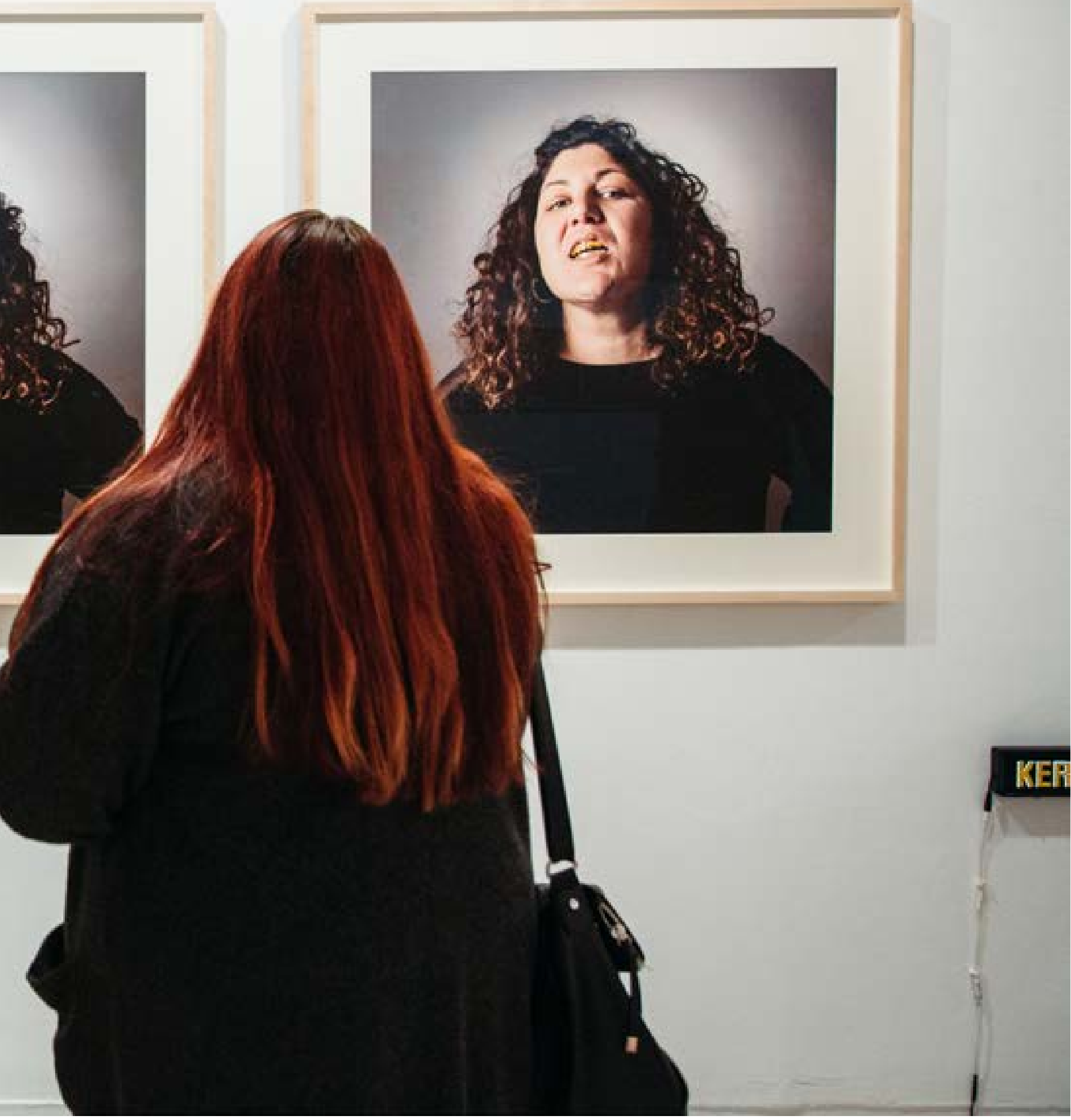

S postava izložbe Moja umjetnost je moja stvarnost, Mali Salon, Muzej moderne i suvremene umjetnosti, Rijeka, 2018. Foto: Stephany Stefan / Von der Ausstellung Meine Kunst ist meine Realität, Kleiner Salon des Museums für moderne und zeitgenössische Kunst, Rijeka, 20I8. Foto: Stephany Stefan $\uparrow$ 
мт S obzirom da izložba obilježava stogodišnjicu završetka Prvoga svjetskog rata, pojedini prezentirani radovi bave se sjećanjima na nasilne društvene prilike i trenutke u osobnoj i društvenoj povijesti. Vrijedi ovdje istaknuti dva foto-istraživačka rada: fotografsku seriju Valérie Leray, Mjesto bez imena, koja služi kao dokument određenog povijesnog trenutka, a kroz prikaze lokacija nekadašnjih romskih sabirnih logora iz Drugoga svjetskog rata. Drugi rad je fotografska serija Mete poznate njemačke fotografkinje Herlinde Koelbl. Na koji način ove fotografije progovaraju o ratnim stradanjima? U čemu leži njihova snaga osim u snažnoj estetskoj komponenti?

sкм Leray Valérie se bavi analizom samog fotografskog medija i njegove istorijske uloge kao svedočanstva i artefakta potrebnog za rekonstrukciju događaja, kao i ispitivanjem odnosa istinitog i lažnog u ovom procesu i mogućnostima manipulacije informacijama i slikama. Geopolitički i geoistorijski kontekst od posebne je važnosti za autorku, koja u seriji radova Mesta bez imena (2006-2015) istražuje mesta romskih sabirnih kampova tokom Drugog svetskog rata u Francuskoj i Evropi, čija se zaboravljena prošlost otkriva činom fotografskog i video beleženja. Polazište opsežnog istraživačkog projekta je njena lična perspektiva i porodična istorija, koju dalje nadograđuje antropometrijskim slikama i istorijskim dokumentima. Važnost projekta ogleda se i u mogućnosti rasvetljavanja i novog sagledavanja istorije Roma u Evropi, rekontekstualizaciji individualnog i kolektivnog pamćenja te doprinosa koji nova saznanja mogu pružiti savremenim društvenim procesima.

Herlinde Koelbl, istaknuta fotografkinja iz Nemačke, serijama svojih radova od 1970-ih godina do danas bavi se istraživanjem društvenih slojeva i odnosa kroz proces beleženja ljudi i događaja. U seriji fotografija i video zapisa Targets (20122016) usmerena je na provokativnu temu međunarodnih vojnih aktivnosti koje čine udarne vesti globalnih medija. Za potrebe istraživanja, tokom šest godina je posetila dvadeset vojnih kampova širom sveta i beležila poligone za vežbu vojnika-scenografiju budućih ratova ispunjenu lažnim arapskim selima i lavirintima betonskih bunkera. Posebnu pažnju je usmerila na inscenirane mete, kao i na realne vojnike koje je portretisala i intervjuisala. Gotovo potresnim scenama analizirala je realno i imaginarno u polju vojnih sukoba, ukazujući na gorući problem kontinuiranih destruktivnih politika i stalne ratne aktivnosti u svetu.

U njihovim pristupima uočljivo je više razlika, od vremenske dimenzije-Leray Valérie se bavi mestima progona Roma tokom Drugog svetskog rata, a Herlinde Koelbl savremenim vojnim kampovima-do razlike u ličnom i opštem pristupu temi. Ali, iako usmerene na drugačije istorijske situacije, mesta i poglede, ove dve umetnice ukazuju na iste društveno-političke probleme, masovno nasilje i stalno prisutnu agresiju nad potlačenim.

U svojem tekstu u katalogu izložbe govorite o arhivima i kolekcijama kao primarnim izvorima znanja koji imaju moć da, između ostaloga, stvaraju povijest i utječu na suvremeno viđenje identiteta i njegov razvoj. U tom kontekstu spominjete i metodologiju akumuliranja kao koncept koji može potaknuti centre moći na angažiraniji pristup pitanjima društvene ravnopravnosti. Na što točno mislite kada govorite o metodologiji arhiviranja i koliko je ista prisutna na samoj izložbi u Malom salonu?

SKM Dokumentiranjem, arhiviranjem i kolekcioniranjem akumuliraju se znanja koja imaju moć da stvaraju istoriju, odrede vrednost umetničkih pojava, ličnosti i umetničkih dela, utiču na savremeno viđenje identiteta i njegov budući razvoj. Projekat polazi od ideje da, iako su arhivi i kolekcije „primarni izvori” koji nose obeležje neutralnosti, već sama metodologija akumuliranja predstavlja koncept koji angažuje društvene, političke i tehnološke moći koje na različite načine mogu pristupiti pitanjima društvene ravnopravnosti (rasne, nacionalne, rodne, 
Akzeptanz und der Annahme der neuen Umgebung. Aufgrund von politischen und wirtschaftlichen, aber auch persönlichen und familiären Gründen hat sie diese Art von Risiko selbst erfahren. Die Videoarbeit Odlazak/Preko zida [Abstieg/Über die Mauer] (20I7), die während des Residency-Programms auf Malta realisiert wurde, beschäftigt sich mit der Frage der Heimat und der Ungewissheit, die eine Veränderung der Lebensmitte mit sich bringt, sowie des Gefühls von Unsicherheit, Entfremdung und Isolierung, die sowohl für Migranten als auch für Angehörige anderer Randgruppen charakteristisch sind. Das Video dokumentiert die intime Beziehung der Autorin mit der neuen Umgebung, einem symbolischen Paradiesgarten, der von einer hohen Mauer umgeben ist, die sie zu überspringen versucht.

Die Videoarbeit dieser Autorin sowie die Arbeiten von Branislav Nikolić und Selman Trtovac sind Bestandteil der Residency-Programme im Rahmen des internationalen EU-Projektes Risk Change, an dem sich das Museum für moderne und zeitgenössische Kunst Rijeka und das Museum der zeitgenössischen Kunst Vojvodina aus Novi Sad, aus dem ich komme, gemeinsam beteiligen, sodass in gewisser Weise das Projekt Risk Change, das auf die Untersuchung der Migrationen ausgerichtet ist, ein weiteres Bindeglied mit der Ausstellung My Art is My Reality und ihren Akteuren darstellt. Ausgewählte Autoren / Autorinnen haben im Verlauf ihrer Aufenthalte in neuen Umgebungen die Migration, Veränderungen, Risiken, aber auch die Position der Besonderheit des Ortes und ihrer Identität in ihm untersucht.

Selman Trtovac befasst sich auch in seiner Arbeit Riječka linija [Rijekas Linie] (20I8) mit seinem Hauptthema-der Kontextualisierung der Linie als symbolischer Idee und als Wegweiser sowohl im formalen als auch im zeitlichen und räumlichen Sinne. Der Autor kam im Rahmen eines Residency-Programms nach siebenundzwanzig Jahren erneut nach Rijeka und realisierte eine Videoarbeit in Form einer Performance, bei der er seinen Sohn tragend vom Ort, an dem das Museum für moderne und zeitgenössische Kunst früher stand, zum Ort ging, an dem das Museum für moderne und zeitgenössische Kunst jetzt steht, wo er zum letzten Mal bei der Jugend-Biennale I99I ausstellte. Damit zog er symbolisch die Grenze bzw. räumte der zeitlichen und räumlichen Verbindung, die aus der persönlichen, generationsbedingten und allgemeinen Perspektive des Kriegs im ehemaligen Jugoslawien und der unvermeidlichen Migration der Bevölkerung wichtig ist, einen hohen Stellenwert ein. Das zweite Segment der Arbeit ist eine großformatige Zeichnung, ähnlich seiner vorherigen Serie von Werken, den sog. Energielinien, in denen der Autor durch Verwendung von Graffiti auf Papier, aber auch seines eigenen Bluts das Konzept und die Forschungen über das Verhältnis zwischen Körper und Zeichnung, Linien und Raum, Zeit und Energie sowie die Bewegung der spirituellen Lebenskraft unterstreicht.

Branislav Nikolić gestaltet sein künstlerisches Konzept durch die Anwendung einer spezifischen Methodik des Sammelns und Recyclings von Abfallstoffen, eines Prinzips, das dem beim Bau vorübergehender Roma-Siedlungen angewandten Prinzip nahe kommt. Die in situ Collagen oder situierten Objekte und Installationen, die aus einer Kombination von verschiedenen bunten, teuren und ausrangierten Materialien bestehen, entwickeln sich in einer Reihe von Arbeiten unter dem gemeinsamen Namen Sekundärarchitektur, die er in vielen Ausstellungs - und alternativen Räumen realisiert. Das Projekt Ispovedaonica [Beichtstuhl] (20I8) entstand nach der ursprünglichen Idee von Hermann Glettler, einem zeitgenössischen österreichischen Künstler und dem jetzigen Bischof in Innsbruck, ebenfalls aus Sekundärrohstoffen und im Dialog mit den Bewohnern von Roma-Siedlungen während seines Aufenthalts in Rijeka. Das Kunstwerk, das zugleich auch sakrales Objekt sein kann, weist auf die Bedürfnisse marginalisierter und diskriminierter gesellschaftlicher Gruppen zur Verwirklichung ihrer eigenen Rechte auf Gleichheit hin. 
seksualne, ekonomske, političke, obrazovne...). Epistemološka uloga arhiva i muzejskih kolekcija, kao i njihov simbolički kapital, srazmerni su i njihovoj lociranosti u sistemu produkcije moći. Digitalna tehnologija je podstakla talas fasciniranosti arhivima uvodeći nas u novu eru arhivske groznice (J. Derrida). Jedna krajnost ovog trenda je romantizacija prošlosti i ukidanje političkog kao deo namernog ili slučajnog dizajna pamćenja. Deo ovog istog procesa de-re-politizacije je uvođenje ideološkog ili aktuelnog realpolitičkog kao načina na koji se sećamo. Relaciju između pamćenja i arhiva određuje aporija arhivske groznicenaizlged proturečan zahtev da (ne) zaboravimo arhiv, kako bi se dogodilo pamćenje. Takođe, pojam muzeja kao institucije koja tradicionalno konstituiše svoju društvenu ulogu kroz akt akumulacije i brige o artefaktima i drugim objektima od umetničke, kulturne ili naučne vrednosti, u sebi kao centralni diskurs sadrži arhivizaciju, u okviru koje se konstituiše identitet muzeja u procesima memorizacije.

Umetnici koriste studije slučaja iz prošlosti ili procese arhiviranja i kolekcioniranja kao načine kreiranja sopstvenih resursa za istraživanje politike sećanja ili aktuelnih društvenih pozicija. Neki od takvih primera na izložbi su radovi Leray Valérie koja polazište ima u arhivima romskih sabirnih logora, Andréa Jenö Raatzscha koji u javnim arhivima analizira građu o Romima i formira specifičnu romsku arhivu, Selme Selman koja koristi arhivu društvenih mreža i internet portala, Herlinde Koelbl koja pristupa procesu kolekcioniranja sekvenci vojnih kampova koje posećuje na različitim lokacijama širom sveta, Emílie Rigove koja kritikuje dominantnu kulturnu politiku izložbi i umetničkih kolekcija te poziciju romskih umetnika i umetnica u njima.

MT Hoće li izložba My Art is My Reality doživjeti svoj nastavak u drugim muzejima, odnosno galerijama izvan Hrvatske; postoje li već planovi?

SkM Izložba će nakon Muzeja moderne i suvremene umjetnosti u Rijeci biti predstavljena u Muzeju savremene umetnosti Vojvodine u Novom Sadu u okviru šireg koncepta propitivanja društvenih i umetničkih savremenih zbivanja. 
мт Eine der kritisch ausgeprägteren Arbeiten ist ganz sicher die Arbeit Vomite, ergo sum! der slowakischen Künstlerin Emillia Rigova, die damit auf den Grundsatz von Descartes „Cogito, ergo sum” bzw. „Ich denke, also bin ich” anspielt. Rigová verweist durch ihre Arbeit auf die Appropriation des Roma-Körpers durch die Geschichte der europäischen Kunst hindurch im Kontext der inneren und äußeren Schaffung einer Roma-Identität. Worauf macht die Autorin genau aufmerksam, wenn es um die vorgenannten Fragen geht? Wenn man die kulturelle Appropriation bedenkt und wie die Roma-Kunst präsentiert wird, wer schafft überhaupt die Kultur der Roma und wie laut ist die Stimme der Unterdrückten, wenn sie durch das Prisma der institutionellen Kunst präsentiert wird?

Emília Rigová zielt mit ihrer intermedialen künstlerischen Praxis auf die Dekonstruktion kultureller und gesellschaftlicher Stereotypen sowie auf die Hinterfragung der Politik des Körpers, des Roma-Körpers und der Roma-Identität im europäischen kulturhistorischen Diskurs ab. Mit der Videoarbeit Vomite, ergo sum! (20I8) und der Fotoserie Keres Kultúra? (20I8) setzt sie die Suche nach den Wegen zur Schaffung einer Roma-Identität und der Position des Roma-Körpers, ausgehend von der persönlichen Perspektive fort, die sie in einen größeren sozialen Kontext stellt. Sie hinterfragt die gesellschaftliche Macht der Repräsentation, Förderung und Bewertung der Roma-Kultur und ihrer Stellung in der Gesellschaft. Wer hat die Macht, sich damit auseinander zu setzen und darüber zu entscheiden, sind einige der Fragen, die die Autorin stellt, während sie auf den Porträts mit goldenen Zähnen zu sehen ist oder Gold aus ihrem Körper erbricht. Der Text, der die Fotoinstallation Keres Kultúra? begleitet, kommt aus dem Romanes und bedeutet: „Schaffen wir Kultur?”. „Das Übergeben ist hier eine Metapher für die Stellung der Roma und wie sie von der Gesellschaft betrachtet werden", meint die Autorin. Mit ihrer Repräsentation analysiert sie kritisch die überwiegend romantisierende Position einer Roma-Frau in der Mainstream-Kultur, in der Kunst und Gesellschaft und verweist auf die oberflächliche Betrachtungsweise der Öffentlichkeit und die Notwendigkeit einer neuen, bewussten Wahrnehmung. „Angesichts der Vorherrschaft der westlich-weißen Geschichtsschreibung und bislang einer Archivierung von Roma Kultur höchstens in ethnologischen Sammlungen...” sind Künstler und Künstlerinnen, die sich kritisch mit der bisherigen Blickweise in der Kunstgeschichte, Museologie und zeitgenössischen Kunstpraxis befassen, ein wichtiges Segment der institutionellen Kritik, das einen neue Perspektive erschließen und neue Fragen und Probleme aufwerfen kann.

мт Da durch diese Ausstellung der hunderste Jahrestag vom Ende des Ersten Weltkriegs begangen wird, befassen sich einige der präsentierten Arbeiten mit den Erinnerungen an gewalttätige gesellschaftliche Umstände und Augenblicke in der persönlichen und gesellschaftlichen Geschichte. Es gilt hier zwei FotoForschungsarbeiten hervorzuheben: die Foto-Serie von Valérie Leray, Orte ohne Namen, dokumentiert durch die Darstellung der Orte, an dem sich im Zweiten Weltkrieg die Internierungslager für Roma befanden, einen bestimmten historischen Zeitpunkt. Die zweite Arbeit ist die Foto-Serie Zielscheiben der bekannten deutschen Fotografin Herlinde Koelbl. Wie zeugen diese Fotografien von den Kriegsleiden? Worin liegt ihre Kraft, außer in der ausgeprägten ästhetischen Komponente?

sкм Leray Valérie beschäftigt sich mit der Analyse des Mediums der Fotografie selbst, seiner historischen Rolle als Zeugnis und Artefakt, das für die Rekonstruktion von Ereignissen benötigt wird, sowie der Untersuchung des Verhältnisses zwischen wahr und falsch in diesem Prozess und den Möglichkeiten zur Manipulation von Informationen und Bildern. Der geopolitische und geohistorische Kontext ist für die Autorin von besonderer Bedeutung, die in der Serie Mesta bez imena [Orte ohne Namen] (2006-20I5) Orte erforscht, an denen sich während des Zweiten Weltkriegs in Frankreich und Europa die Internierungslager für Roma befanden, deren vergessene Vergangenheit durch den Akt der Foto- und Videoaufnahme
Rigová, „Vomite, ergo sum!”, 77 . Pankok, „Transforming Powers. The contemporary Art of Sinti and Roma”, 26-27. 


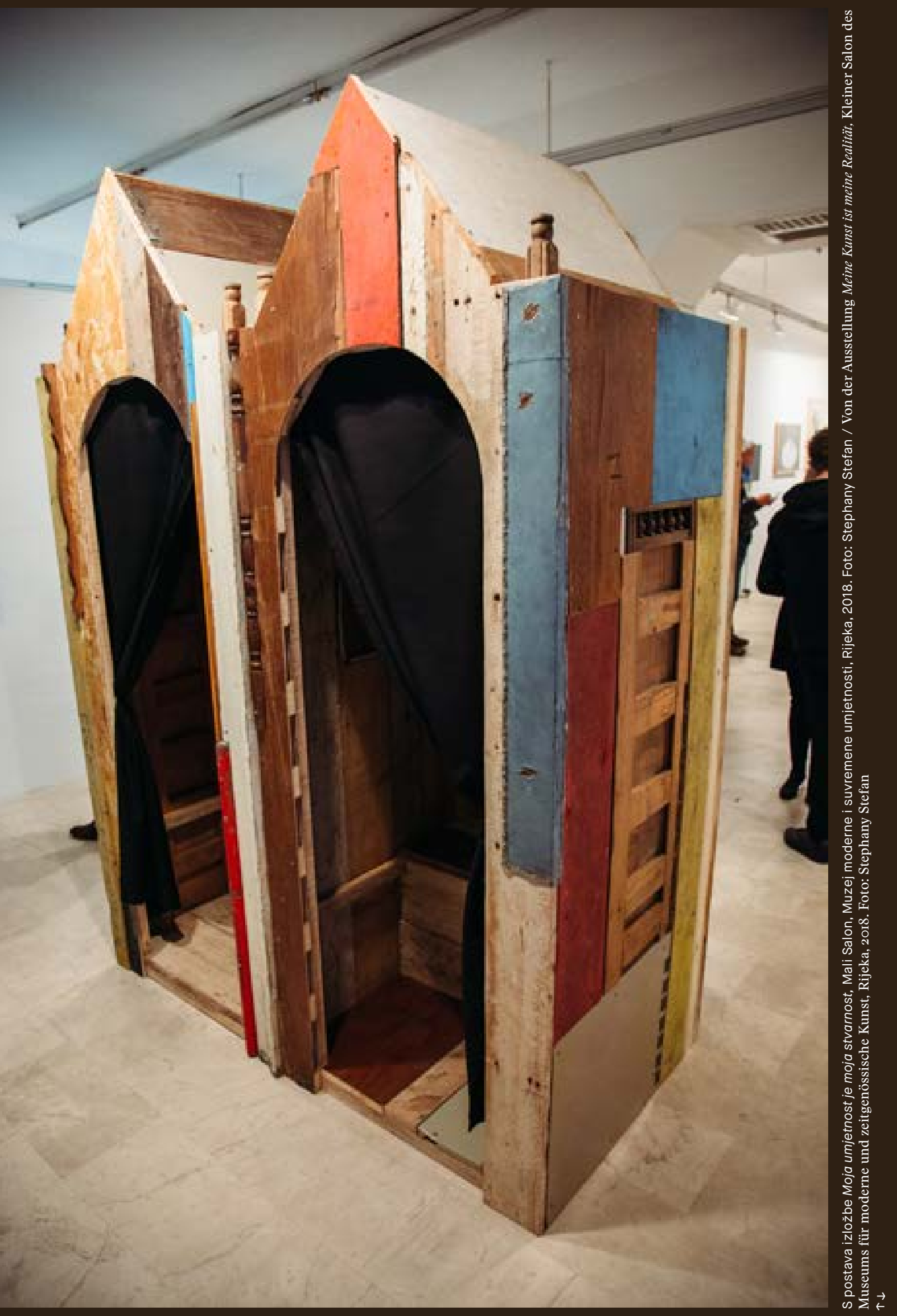


aufgedeckt wird. Ausgangspunkt dieses umfangreichen Forschungsprojekts ist die persönliche Perspektive und Familiengeschichte, die mit anthropometrischen Bildern und historischen Dokumenten ergänzt wird. Die Bedeutung des Projekts spiegelt sich auch in der Möglichkeit wider, die Geschichte der Roma in Europa aufzuklären und neu zu überdenken, die individuelle und kollektive Erinnerung in einen neuen Kontext zu setzen sowie durch die neuen Erkenntnisse einen Beitrag zu den zeitgenössischen gesellschaftlichen Prozessen zu leisten.

Herlinde Koelbl, renommierte deutsche Fotografin befasst sich in ihren Werken seit den 70 -er Jahren des vergangenen Jahrhunderts bis heute mit der Erforschung gesellschaftlicher Schichten und Beziehungen durch das Aufzeichnen von Menschen und Ereignissen. In der Serie von Foto- und Videoaufzeichnungen Targets [Zielscheiben] (2OI2-2OI6) konzentriert sie sich auf das provokante Thema internationaler militärischer Aktivitäten, die die Hauptnachrichten der globalen Medien sind. Sie besuchte im Verlauf von sechs Jahren zwanzig Militärlager auf der ganzen Welt und zeichnete militärische Trainingsparcours auf-die Szenografie zukünftiger Kriege, die mit nachgestellten arabischen Dörfern und einem Labyrinth aus Betonbunkern ausgefüllt waren. In ihrem Fokus waren insbesondere die inszenierten Ziele sowie die echten Soldaten, die sie besonders porträtierte und interviewte. Mit fast erschütternden Szenen analysiert sie das Realistische und Imaginäre im Bereich der militärischen Konflikte und weist so auf das brennende Problem der kontinuierlichen destruktiven Politiken und der anhaltenden Kriegshandlungen weltweit hin.

In ihren Ansätzen sind mehrere Unterschiede zu erkennen, von der zeitlichen Dimension-Leray Valérie befasst sich mit Orten der Verfolgung der Roma im Zweiten Weltkrieg und Herlinde Koelbl mit zeitgenössischen Militärcamps — bis hin zu der persönlichen und allgemeinen Behandlung des Themas. Aber obwohl sie auf unterschiedliche historische Situationen, Orte und Ansichten fokussiert sind, weisen diese beiden Künstlerinnen auf die gleichen gesellschaftspolitischen Probleme, Massengewalt und die ständig anwesende Agression gegen die Unterdrückten hin.

мт In Ihrem Text im Katalog bezeichnen Sie Archive und Sammlungen als Primärquellen des Wissens, die unter anderem die Macht haben, Geschichte zu schreiben und die zeitgenössische Vision der Identität und ihre zukünftige Entwicklung zu beeinflussen. In diesem Zusammenhang erwähnen Sie auch die Methodik der Anhäufung als Konzept, das die Zentren der Macht dazu anregen kann, sich engagierter mit den Fragen der sozialen Gleichbehandlung zu befassen. Was verstehen Sie genau unter der Methodik der Archivierung und in welchem Maße ist sie auf der Ausstellung im Kleinen Salon vertreten?

Durch das Dokumentieren, Archivieren und Sammeln wird Wissen angehäuft, das die Macht hat, Geschichte zu schreiben, den Wert der künstlerischen Erscheinungen, Persönlichkeiten und Kunstwerke zu bestimmen, die moderne Vision der Identität und ihre zukünftige Entwicklung zu beeinflussen. Das Projekt beruht auf der Idee, dass, obwohl die Archive und Sammlungen neutrale „Primärquellen” darstellen, bereits die Methodik der Anhäufung selbst ein Konzept darstellt, das zum Engagement der gesellschaftlichen, politischen und technologischen Mächte führt, die die Fragen der gesellschaftlichen Gleichbehandlung (rassisch, ethnisch, geschlechtsspezifisch, sexuell, wirtschaftlich, politisch, pädagogisch...) auf unterschiedliche Weise behandeln können.

Die erkenntnistheoretische Rolle von Archiven und Museumssammlungen sowie ihr symbolisches Kapital stehen im Verhältnis zu ihrem Ort im System der Produktion der Macht. Die digitale Technologie hat eine Welle der Faszination für Archive ausgelöst und uns in eine neue Ära des Archivfiebers (J. Derrida) eingeführt. Ein Extrem dieses Trends ist die Romantisierung der Vergangenheit und die 


\section{LITERATURA / LITERATUR}

Kojić Mladenov, Sanja, ur./Ed. Moja umjetnost je moja stvarnost / Meine Kunst ist meine Realität, katalog izložbe/Ausstellungskatalog. Rijeka: Muzej moderne i suvremene umjetnosti, 2018

Pankok, Moritz. „Snaga koja mijenja: Suvremena umjetnost Sinta i Roma / Transforming Powers. The contemporary Art of Sinti and Roma", 26-27. U/In: Moja umjetnost je moja stvarnost / Meine Kunst ist meine Realität, katalog izložbe/Ausstellungskatalog, ur./Ed. Sanja Kojić Mladenov. Rijeka: Muzej moderne i suvremene umjetnosti, 2018.

Rigová, Emília. „Vomite, ergo sum!”, 77. U/In: Moja umjetnost je moja stvarnost / Meine Kunst ist meine Realität, katalog izložbe/Ausstellungskatalog, ur./Ed. Sanja Kojić Mladenov. Rijeka: Muzej moderne i suvremene umjetnosti, 2018. 
Beseitigung des Politischen als Teil des absichtlichen oder zufälligen Designs des Gedächtnisses. Teil dieses Ent-Wieder-Politisierungsprozesses ist die Einführung des ideologischen oder aktuellen Realpolitischen als Art und Weise, wie wir uns erinnern. Das Verhältnis zwischen dem Gedächtnis und dem Archiv wird durch die Aporie des Archivfiebers bestimmt - eine auf den ersten Blick widersprüchliche Aufforderung, das Archiv (nicht) zu vergessen, damit Erinnerungen entstehen können. Auch der Begriff des Museums als Institution, die traditionell ihre soziale Rolle durch Akkumulation und Pflege von Artefakten und anderen Objekten von künstlerischem, kulturellem oder wissenschaftlichem Wert begründet, umfasst als zentralen Diskurs den Archivierungsprozess, in dessen Rahmen die Identität des Museums in Erinnerungsprozessen gestaltet wird.

Künstler verwenden Fallstudien aus der Vergangenheit oder Archivierungs- und Sammelprozesse, um ihre eigenen Ressourcen zur Untersuchung der Erinnerungspolitiken oder aktueller gesellschaftlicher Positionen zu schaffen. Einige Beispiele auf der Ausstellung dafür sind die Arbeiten von Leray Valérie, die ihren Ausgangspunkt in den Archiven der Roma-Internierungslager hat, André Jenö Raatzsch, der in öffentlichen Archiven das Material über die Roma analysiert und ein besonderes Roma-Archiv gestaltet, Selma Selman, die das Archiv der sozialen Netzwerke und Internetportale verwendet, Herlinde Koelbl, die den Prozess des Sammelns von Sequenzen aus Militärlagern einleitet, die sie an verschiedenen Orten weltweit besucht, Emília Rigova, die die dominante Kulturpolitik der Ausstellungen und Kunstsammlungen sowie die Stellung der Roma-KünstlerInnen darin kritisiert.

мт Wird die Ausstellung My Art is My Reality auch eine Fortsetzung in anderen Museen bzw. Galerien außerhalb Kroatiens erleben; gibt es schon entsprechende Pläne?

sкм Die Ausstellung wird nach dem Museum für moderne und zeitgenössische Kunst in Rijeka im Rahmen eines breiteren Konzeptes zur Hinterfragung gesellschaftlicher und zeitgenössischer künstlerischer Ereignisse im Museum für zeitgenössische Kunst Vojvodina in Novi Sad vorgestellt werden. 